\title{
Recolonization of soft-sediment ice scours on an exposed Arctic coast
}

\author{
Kathleen E. Conlan ${ }^{1, *}$, Rikk G. Kvitek ${ }^{2,3}$ \\ ${ }^{1}$ Canadian Museum of Nature, PO Box 3443, Station D, Ottawa, Ontario K1P 6P4, Canada \\ ${ }^{2}$ Moss Landing Marine Laboratories, PO Box 450, Moss Landing, California 95039, USA \\ ${ }^{3}$ Present address: Earth System Science and Policy Institute, California State University Monterey Bay, 100 Campus Center, \\ Seaside, California 93955, USA
}

\begin{abstract}
Ice scour is the most disruptive and widespread physical disturbance that naturally affects the coastal benthos in polar waters, where it creates a mosaic of disturbances in various stages of recolonization. The purpose of this study was to (1) determine the timing and sequence of biotic recovery following ice scour disturbance of soft sediment and (2) test the general hypothesis that ice scour increases biotic diversity in high-latitude benthic communities. The study area was a $6.6 \mathrm{~km}$ length of Barrow Strait along the exposed coast of Cornwallis Island in High Arctic Canada. Corecollected $\left(0.0075 \mathrm{~m}^{2}\right)$ macrofauna $(\geq 0.5 \mathrm{~mm})$ inhabiting 19 scours at 12 to $28 \mathrm{~m}$ depth were sampled during open water in August of 1991 to 1996 and again in 1999. We repeat-sampled 2 scours for 6 summers, 3 scours for 3 summers, and 2 for 2 summers, while the other 12 scours were sampled once. Sampling was severely limited by availability of open water which was constrained by frequent invasion of the study area by drift ice. Young ice scours were refugia for the dorvilleid polychaete Ophryotrocha spatula. Its numbers declined precipitously as the scours aged. Other early colonists maintained or increased their abundance. Most of the later colonists significantly increased in abundance as the scours aged despite the presence of the early colonists. Abundance, biomass and species richness increased progressively with scour ageing but did not significantly exceed that in the unscoured community. Thus, although the scours differed from the unscoured reference community in species composition, they were not havens for species-rich or highly different assemblages (at least not among core-collected macrofauna). Recolonization of ice scours $\leq 9 \mathrm{yr}$ old fitted a linear model. Assuming that further colonization would continue to be linear, the 2 scours monitored the longest had achieved 65 to $84 \%$ recolonization by Ages 8 to 9. The unscoured reference community was significantly more diverse, massive and abundant where disturbance was a chronic but infrequent occurrence, compared to where it was protected from ice scour by an offshore rise. Thus, ice scour appears to have a positive effect on the benthos of this coast.
\end{abstract}

KEY WORDS: Ice scour $\cdot$ Recolonization $\cdot$ Disturbance $\cdot$ Benthos $\cdot$ Arctic

\section{INTRODUCTION}

Soft-sediment ice scour, the process by which the benthos is gouged by grounded ice, can be a largescale and repetitive event that affects polar and cold-temperate areas in both hemispheres. Besides destroying the benthos, ice scour also modifies seafloor topography, changes the sediment characteristics and bottom current flow, and bulldozes, deforms and resuspends the sediment (Lien et al. 1989, Lewis \& Blasco 1990, Rearic et al. 1990, Woodworth-Lynas et al. 1991 and references therein). Biological consequences are loss of benthic biomass, modification of abundance and diversity patterns, and changes in community structure and function (Conlan et al. 1998, Gutt 2001 and references therein). Physical consequences are 
long-term changes to seabed geomorphology and damage of seafloor structures such as cables, wellheads and pipelines (Lewis \& Blasco 1990).

In the ocean, ice can reach to depths of $550 \mathrm{~m}$ (Barnes \& Lien 1988, Dowdeswell et al. 1993) and scour paths can be up to $350 \mathrm{~m}$ wide, $15 \mathrm{~m}$ deep and $15 \mathrm{~km}$ long (Hotzel \& Miller 1983). Ice scour affects lakes as well. The floor of Lake Erie has ice scours up to $100 \mathrm{~m}$ wide, $2 \mathrm{~m}$ deep and $6 \mathrm{~km}$ long in water depths of as much as $25 \mathrm{~m}$ (Grass 1998). The seabed may preserve ice scour marks for many years. Blasco et al. (2000) estimated the age of a $50 \mathrm{~km}$ long scour in the Beaufort Sea to be $2000 \pm 200 \mathrm{yr}$. Ice scours in waters $>550 \mathrm{~m}$ in the Atlantic and Southern Oceans date back to glacial times (Pereira et al. 1985, Barnes \& Lien 1988, Josenhans \& Woodworth-Lynas 1988). The Canadian glacial lakes Ojibwa and Agassiz show clear evidence of ice scour on their extinct lake-beds (Dionne 1977, Woodworth-Lynas \& Guigné 1990).

In ice-infested areas, ice scours may be sufficiently frequent to obliterate undisturbed sediment (Lewis \& Blasco 1990). Indeed, many polar nearshore environments may be in a permanent state of recovery from ice effects (Barnes 1999). At greater depths, ice scours may comprise discrete and separate events that afford the opportunity of studying numerous disturbances with adequate replication. Such naturally occurring, repetitive and large disturbances are difficult to find in the marine benthos. Trawling would be an analagous unnatural disturbance to the seabed, but trawling incisions are not as wide or as deep as those created by large ice, and do not last as long (Jones 1992, Service \& Magorrian 1997). Some types of dredging may produce sediment incisions that are deeper than and at least as large as some ice scours, however (Newell et al. 1998).

Conlan et al. (1998) found that the seabed in Barrow Strait along southern Cornwallis Island in the Canadian Arctic Archipelago was ideal for studying the biological effects of soft-sediment ice scour because the seabed was a hard-packed, cobble-coated glacial till which clearly preserved ice gouges over decades to possibly centuries. Sidescan sonar maps of $7.4 \mathrm{~km}^{2}$ of coast showed that the seabed at 10 to $30 \mathrm{~m}$ depth is a mosaic of discrete scours of varying stages of recovery. Scours analyzed by Blasco et al. (2000) in this depth range were found to have incised 0.5 to $2.5 \mathrm{~m}$ of the seabed, were 10 to $400 \mathrm{~m}$ wide and 25 to $1700 \mathrm{~m}$ long, and had rise-ups as great as $3 \mathrm{~m}$. Over $8 \mathrm{yr}$ of repeat mapping, 26 new scours were identified, with an impact rate of 1 to 7 impacts $\mathrm{yr}^{-1}$. Repeat-mapping also enabled discovery of new scours of known age, and hence the pattern and rate of biological recolonization and physical degradation (recovery) of the scours.
Recolonization of disturbances progresses through typical stages of early dominance by opportunistic species with high fecundity, rapid growth and short life cycles, leading to an ecologically diverse mix of equilibrium species with greater investment in growth, reproduction and predator avoidance (MacArthur \& Wilson 1967, Pearson \& Rosenberg 1978, McCook 1994, Newell et al. 1998). The success of an organism in any region of this environmental gradient will be determined by its life history traits, modified by such factors as availability, disturbance levels, history and the effects of co-occurring species (McCook 1994). Given that ice scour is one of the 5 most significant disturbances to Earth's ecosystems (Gutt \& Starmans 2001), the process of succession has been little studied compared to similar impacts caused by dredging and trawling (Newell et al. 1998). In most soft-sediment ice scour studies, succession has been inferred through comparison of the communities in scours of different age (e.g. Gutt et al. 1996, Conlan et al. 1998, Gutt \& Starmans 2001, Lee et al. 2001a, Gerdes et al. 2003, Gutt \& Piepenburg 2003, Knust et al. 2003). Lack of temporal studies has probably been due to logistic difficulties and the slowness of polar succession. Temporal studies of recruitment after ice scour have so far been made only for rapidly growing meiofaunal communities (Lee et al. 2001b, Peck et al. 1999), macrofauna over a short timescale $(\leq 250 \mathrm{~d}$; Peck et al. 1999) and for relatively simple species assemblages on hard substrates (McCook \& Chapman 1993, Barnes 1999).

The present study adds a temporal component to the study of macrofaunal recolonization of soft-sediment subtidal ice scours. It embraces a $9 \mathrm{yr}$ period of ice scour recovery (1991 to 1999). Although too short to cover the complete sequence of physical degradation and community succession, it has enabled us to determine the process of recolonization and compare it with recovery rates in other regimes. We report here on community patterns in 19 scours varying from newly formed to old. Of these, 9 were of known age; 7 were sampled over more than $1 \mathrm{yr}$, with 2 being resampled over 6 yr. The opportunity to repeat-sample and to replicate disturbance events enabled testing of the following hypotheses: (1) scours at every stage of physical degradation differ significantly in community composition from the undisturbed community outside; (2) the community composition of the scours reflects their physical state of degradation; (3) elevated scour berms (sediment ploughed up to the sides of the trough, clearly delineating the scour from unscoured reference seabed) differ in community makeup from the centrally incised trough; (4) scours are refugia for fauna; (5) areas vulnerable to scouring support different communities than areas protected from disturbance. 


\section{MATERIALS AND METHODS}

Study site. The study was conducted each August from 1991 to 1996 and again in 1999 in the exposed Barrow Strait on the southern coast of Cornwallis Island in the Canadian Arctic Archipelago (Fig. 1). This area is never totally ice-free. It is covered in seaice from about mid-September to late July, and after ice breakup it receives first-year and multi-year ice predominantly from the north and east (Welch et al. 1992). It was not possible to sample at other times of year due to logistic and licensing constraints. This $6.6 \mathrm{~km}$ strip of coast was repeat-mapped each August using an EG\&G 260TH dual frequency $(100 / 500) \mathrm{kHz}$ sidescan sonar. Bathymetry was determined by a $208 \mathrm{kHz}$ innerspace 448 digital fathometer. Scour positions were recorded by differential GPS.

Sampling design. Assessment of the physical appearance of the scours, both on sidescan mosaics and by direct diver observation, indicated that the scours

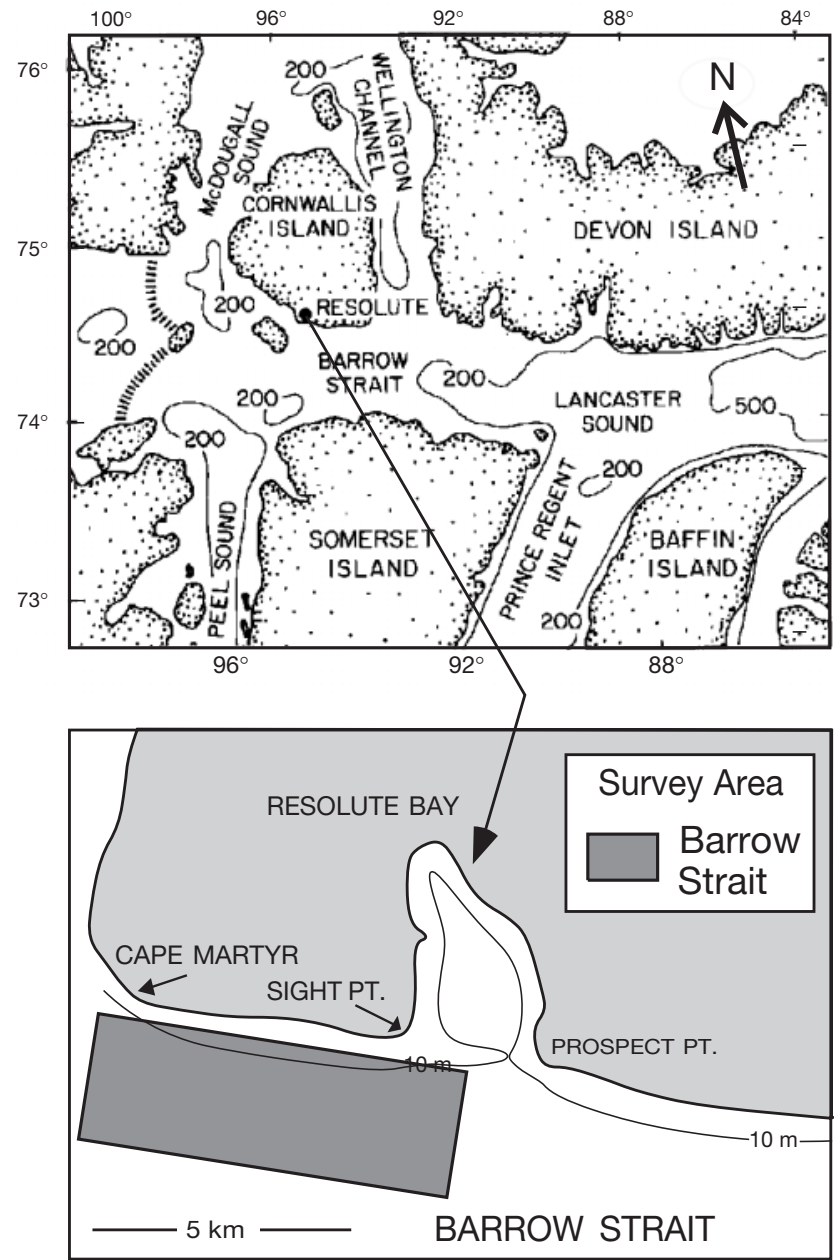

Fig. 1. Study area on coast of Cornwallis Island in High Arctic Canada, between Prospect Point and Cape Martyr in Barrow Strait did not show a continuum of degradation but rather several discrete states of erosion. Thus, the scours were grouped by experienced scour geomorphologists into separate age categories ('known-age scours') using the criteria sediment composition, berm and trough contour, and presence of sediment fractures and ice imprints (Blasco et al. 2000). Subsequently, 19 scours were selected for biological study (Table 1). Criteria for scour selection were that they were separate from other scours and collectively embraced all 4 physical age categories. Unlike the Antarctic ice scours described by Gutt et al. (1996), Peck et al. (1999), Gutt \& Starmans (2001) and Gerdes et al. (2003), these scours had pronounced berms, which were elevated 1 to $5 \mathrm{~m}$ above the troughs (Table 1). The presence of a distinct berm may have been due to the difference in sediment and the touch-down force of the gouging ice. The clear physical distinctiveness of the ice scours enabled us to avoid the circularity of using biological criteria to age the scours for biological recolonization.

Repeat-mapping the following year enabled the discovery of new scours that had formed since the previous year's survey. As long as ice conditions allowed it, these new, known-age scours were sampled in subsequent years to determine the pattern and rate of recolonization and the process of physical degradation. Fractures in the new scour 'Groovy' were also sampled $1.8 \mathrm{yr}$ after it formed to examine colonization of unusual scour features. Of the 19 scours sampled over 1991 to 1999 in Barrow Strait, 1 was sampled in 1991, 4 in 1992, 6 in 1993, 6 in 1994, 9 in 1995, 7 in 1996, and 4 in 1999. The 1 scour sampled in 1991 formed part of the study of Conlan et al. (1998). Reference sites, located in sediment that showed no physical appearance of disturbance but close to a scour within the survey area, were also sampled each year. Nine of the scours were of known age. For the unknown-age scours, physical criteria were used to give a rough age (see next subsection). Macrofauna $\geq 0.5 \mathrm{~mm}$ were sampled with 6-replicate $0.0075 \mathrm{~m}^{2}(9.8 \mathrm{~cm}$ diameter $)$ cores taken haphazardly by divers on the scour troughs and berms and in the reference sediment outside the scours. In total, 480 cores were analyzed for recolonization (Table 1), 58 for unusual scour features, and 36 for scour-intensity effects.

Of the known-age scours, 7 were sampled over more than $1 \mathrm{yr}$, with 2 re-sampled for 6 yr. The number of scours sampled each year was constrained by the frequency of access (controlled by drift ice), weather, length of the field season, manpower, logistic limitations and funding and licensing constraints. Of particular concern was the frequent loss of access to the scours due to the wind and current-driven movement of drift ice in Barrow Strait. In some years, access was limited to only a third of the field season. 
Table 1. Physical characteristics, locations, sampling dates, ages, and state of recolonization of scours in Barrow Strait. AMOSIM 1-R and p-values are measures of resemblance of the group of 6 replicates taken from each scour contour on each date to all outside reference samples combined. UTM: Universal Time Mercator; T to B height: trough to berm height; phys.: physical age group; Poly. sp.: polychaete replicates identified to species; O: outside; B: berm; T: trough; N: new; R: recent; M: middle-aged; ${ }^{*}$ :p $<0.05_{;}{ }^{* *}:<0.01$

\begin{tabular}{|c|c|c|c|c|c|c|c|c|c|c|c|c|c|c|c|}
\hline $\begin{array}{l}\text { Location } \\
\text { (UTM easting; } \\
44----E)\end{array}$ & $\begin{array}{l}\text { Scour } \\
\text { name }\end{array}$ & $\begin{array}{l}\text { Orien- } \\
\text { tation } \\
\left({ }^{\circ} \mathrm{E} \text { of } \mathrm{N}\right)\end{array}$ & $\begin{array}{r}\text { Sc } \\
\text { length } \\
(\mathrm{m})\end{array}$ & $\begin{array}{l}\text { ur } \\
\text { width } \\
(\mathrm{m})\end{array}$ & $\begin{array}{l}\text { T to B } \\
\text { height } \\
\text { (m) }\end{array}$ & Year & $\begin{array}{l}\text { Con- } \\
\text { tour }\end{array}$ & $\begin{array}{l}\text { Water } \\
\text { depth } \\
\text { (m) }\end{array}$ & $\begin{array}{c}\text { Age } \\
\text { (max.) }\end{array}$ & $\begin{array}{l}\text { yr ) } \\
\text { phys. }\end{array}$ & $1-\mathrm{R}$ & $\mathrm{p}$ & $\begin{array}{c}\text { Gravel } \\
(\%)\end{array}$ & $\begin{array}{c}\text { Fines } \\
(\%)\end{array}$ & Poly. sp \\
\hline \multirow[t]{2}{*}{5300} & Snake & 305 & 275 & 7 & 1 & 96 & B & 18 & 1 & $\mathrm{~N}$ & 0.242 & $0.001^{* *}$ & & & \\
\hline & & & & & & 96 & $\mathrm{~T}$ & 19 & 1 & $\mathrm{~N}$ & 0.089 & $0.001^{* *}$ & & & \\
\hline \multirow[t]{8}{*}{4480} & Groovy & 323 & 550 & 47 & 3 & 95 & B & 20 & 1 & $\mathrm{~N}$ & 0.047 & $0.001^{* *}$ & & & \\
\hline & & & & & & 95 & $\mathrm{~T}$ & 23 & 1 & $\mathrm{~N}$ & 0.074 & $0.001^{* *}$ & & & \\
\hline & & & & & & 96 & $\mathrm{O}$ & 21 & & & & & & & \\
\hline & & & & & & 96 & B & 20 & 2 & $\mathrm{R}$ & 0.222 & $0.001^{* *}$ & & & \\
\hline & & & & & & 96 & $\mathrm{~T}$ & 23 & 2 & $\mathrm{R}$ & 0.045 & $0.001^{* *}$ & & & \\
\hline & & & & & & 99 & $\mathrm{O}$ & 21 & & & & & & & \\
\hline & & & & & & 99 & B & 20 & 5 & $\mathrm{R}$ & 0.302 & $0.001^{* *}$ & & & \\
\hline & & & & & & 99 & $\mathrm{~T}$ & 23 & 5 & $\mathrm{R}$ & 0.084 & $0.001^{* *}$ & & & \\
\hline \multirow[t]{2}{*}{4365} & Long & 291 & 535 & 36 & 1 & 96 & B & 19 & $?$ & Old & 0.980 & 0.416 & & & \\
\hline & & & & & & 96 & $\mathrm{~T}$ & 20 & $?$ & Old & 0.537 & $0.008^{* *}$ & & & \\
\hline \multirow[t]{6}{*}{4058} & Elbow & 318 & 203 & 18 & 1 & 95 & B & 20 & $?$ & $\mathrm{M}$ & 0.618 & $0.004^{* *}$ & & & \\
\hline & & & & & & 95 & $\mathrm{~T}$ & 21 & $?$ & M & 0.629 & $0.002^{* *}$ & & & \\
\hline & & & & & & 96 & B & 20 & $?+1$ & M & 0.353 & $0.001^{* *}$ & & & \\
\hline & & & & & & 96 & $\mathrm{~T}$ & 21 & $?+1$ & M & 0.286 & $0.001^{* *}$ & & & \\
\hline & & & & & & 99 & B & 20 & $?+4$ & M & 0.502 & $0.001^{* *}$ & & & \\
\hline & & & & & & 99 & $\mathrm{~T}$ & 21 & $?+4$ & M & 0.952 & 0.300 & & & \\
\hline \multirow[t]{2}{*}{3944} & Foot & 328 & 132 & 19 & 2 & 95 & B & 19 & $?$ & M & 0.759 & 0.162 & & & \\
\hline & & & & & & 95 & $\mathrm{~T}$ & 21 & $?$ & M & 0.870 & 0.162 & & & \\
\hline \multirow[t]{2}{*}{3871} & $\mathrm{Q}$ & 0 & 37 & 8 & 2 & 93 & $\mathrm{O}$ & 14 & & & & & & & 5,6 \\
\hline & & & & & & 93 & $\mathrm{~T}$ & 13 & 1 & $\mathrm{~N}$ & 0.286 & $0.001^{* *}$ & & & $1,2,3,4$ \\
\hline 3816 & Dim & 343 & 345 & 19 & 1 & 93 & $\mathrm{~T}$ & 14 & $?$ & Old & 0.996 & 0.446 & & & 2,3 \\
\hline \multirow[t]{15}{*}{3786} & Lower Molar & $r \quad 328$ & 62 & 19 & 2 & 92 & $\mathrm{O}$ & 13 & & & & & & & \\
\hline & & & & & & 92 & B & 12 & 1 & $\mathrm{~N}$ & 0.232 & $0.001^{* *}$ & & & \\
\hline & & & & & & 92 & $\mathrm{~T}$ & 15 & 1 & $\mathrm{~N}$ & 0.048 & $0.001^{* *}$ & & & \\
\hline & & & & & & 93 & $\mathrm{~T}$ & 15 & 2 & $\mathrm{R}$ & 0.161 & $0.001^{* *}$ & & & $1,5,6$ \\
\hline & & & & & & 94 & B & 12 & 3 & $\mathrm{R}$ & 0.374 & $0.001^{* *}$ & 39.40 & 41.03 & \\
\hline & & & & & & 94 & $\mathrm{~T}$ & 15 & 3 & $\mathrm{R}$ & 0.296 & $0.001^{* *}$ & 32.24 & 35.57 & \\
\hline & & & & & & 95 & $\mathrm{O}$ & 13 & & & & & & & \\
\hline & & & & & & 95 & B & 12 & 4 & $\mathrm{R}$ & 0.323 & $0.001^{* *}$ & & & \\
\hline & & & & & & 95 & $\mathrm{~T}$ & 15 & 4 & $\mathrm{R}$ & 0.282 & $0.001^{* *}$ & & & \\
\hline & & & & & & 96 & $\mathrm{O}$ & 13 & & & & & & & \\
\hline & & & & & & 96 & B & 12 & 5 & $\mathrm{R}$ & 0.221 & $0.001^{* *}$ & & & \\
\hline & & & & & & 96 & $\mathrm{~T}$ & 15 & 5 & $\mathrm{R}$ & 0.334 & $0.001^{* *}$ & & & \\
\hline & & & & & & 99 & $\mathrm{O}$ & 13 & & & & & & & \\
\hline & & & & & & 99 & B & 12 & 8 & $\mathrm{R}$ & 0.525 & $0.001^{* *}$ & & & \\
\hline & & & & & & 99 & $\mathrm{~T}$ & 15 & 8 & $\mathrm{R}$ & 0.671 & $0.037^{*}$ & & & \\
\hline 3717 & Incisor & 292 & 39 & 12 & 4 & 92 & $\mathrm{O}$ & 18 & & & & & & & \\
\hline & & & & & & 92 & B & 16 & 2 & $\mathrm{R}$ & 0.028 & $0.001^{* *}$ & & & \\
\hline & & & & & & 92 & $\mathrm{~T}$ & 20 & 2 & $\mathrm{R}$ & 0.154 & $0.001^{* *}$ & & & \\
\hline & & & & & & 93 & $\mathrm{~T}$ & 20 & 3 & $\mathrm{R}$ & 0.266 & $0.001^{* *}$ & & & 1,4 \\
\hline & & & & & & 94 & $\mathrm{O}$ & 18 & & & & & 16.70 & 30.30 & \\
\hline & & & & & & 94 & B & 16 & 4 & $\mathrm{R}$ & 0.295 & $0.001^{* *}$ & 8.17 & 71.77 & \\
\hline & & & & & & 94 & $\mathrm{~T}$ & 20 & 4 & $\mathrm{R}$ & 0.260 & $0.001^{* *}$ & 4.82 & 73.34 & \\
\hline & & & & & & 95 & $\mathrm{O}$ & 18 & & & & & & & \\
\hline & & & & & & 95 & B & 16 & 5 & $\mathrm{R}$ & 0.193 & $0.001^{* *}$ & & & \\
\hline & & & & & & 95 & $\mathrm{~T}$ & 20 & 5 & $\mathrm{R}$ & 0.225 & $0.001^{* *}$ & & & \\
\hline & & & & & & 96 & $\mathrm{O}$ & 18 & & & & & & & \\
\hline & & & & & & 96 & B & 16 & 6 & $\mathrm{R}$ & 0.397 & $0.001^{* *}$ & & & \\
\hline & & & & & & 96 & $\mathrm{~T}$ & 20 & 6 & $\mathrm{R}$ & 0.332 & $0.001^{* *}$ & & & \\
\hline & & & & & & 99 & $\mathrm{O}$ & 18 & & & & & & & \\
\hline & & & & & & 99 & B & 16 & 9 & $\mathrm{R}$ & 0.588 & $0.002^{* *}$ & & & \\
\hline & & & & & & 99 & $\mathrm{~T}$ & 20 & 9 & $\mathrm{R}$ & 0.524 & $0.001^{* *}$ & & & \\
\hline 3690 & Flat-top & 292 & 15 & 12 & & 94 & $\mathrm{~T}$ & 14 & 1 & $\mathrm{~N}$ & 0.003 & $0.001^{* *}$ & 28.65 & 53.40 & \\
\hline & & & & & & 95 & $\mathrm{~T}$ & 14 & 2 & $\mathrm{R}$ & 0.057 & $0.001^{* *}$ & & & \\
\hline & & & & & & 96 & $\mathrm{~T}$ & 14 & 3 & $\mathrm{R}$ & 0.202 & $0.001^{* *}$ & & & \\
\hline 3680 & Old Timer & 339 & 681 & 30 & 2 & 93 & $\mathrm{~T}$ & 17 & $?$ & Old & 1.174 & 0.943 & & & 1,3 \\
\hline & & & & & & 94 & B & 19 & $?+1$ & Old & 1.029 & 0.602 & 8.47 & 31.93 & \\
\hline & & & & & & 94 & $\mathrm{~T}$ & 17 & $?+1$ & Old & 1.093 & 0.766 & 42.28 & 37.69 & \\
\hline 3628 & Crosscut & 349 & 150 & 16 & 2 & 94 & B & 17 & $?$ & $\mathrm{R}$ & 0.565 & $0.002^{* *}$ & & & \\
\hline & & & & & & 94 & $\mathrm{~T}$ & 19 & $?$ & $\mathrm{R}$ & 0.359 & $0.001^{* *}$ & & & \\
\hline 2308 & Harold & 292 & 39 & 12 & 3 & 92 & B & 15 & $?$ & Old & 0.361 & $0.001^{* *}$ & & & \\
\hline & & & & & & 92 & $\mathrm{~T}$ & 18 & $?$ & Old & 0.771 & $0.045^{*}$ & & & \\
\hline 1740 & Sal-1 & 296 & 200 & 28 & 2 & 93 & $\mathrm{~T}$ & 24 & 1 & $\mathrm{~N}$ & 0.227 & $0.001^{* *}$ & & & 1,4 \\
\hline 1568 & Twister & 324 & 65 & 11 & 3 & 92 & $\mathrm{O}$ & 15 & & & & & & & \\
\hline & & & & & & 92 & $\mathrm{~T}$ & 17 & $?$ & M & 0.663 & $0.009^{* *}$ & & & \\
\hline
\end{tabular}


Table 1 (continued)

\begin{tabular}{|c|c|c|c|c|c|c|c|c|c|c|c|c|c|c|c|}
\hline $\begin{array}{l}\text { Location } \\
\text { (UTM easting; } \\
44----E)\end{array}$ & $\begin{array}{l}\text { Scour } \\
\text { name }\end{array}$ & $\begin{array}{l}\text { Orien- } \\
\text { tation } \\
\left({ }^{\circ} \mathrm{E} \text { of } \mathrm{N}\right)\end{array}$ & $\begin{array}{l}\text { Scc } \\
\text { length } \\
(\mathrm{m})\end{array}$ & $\begin{array}{l}\text { our } \\
\text { width } \\
\text { (m) }\end{array}$ & $\begin{array}{l}\text { T to B } \\
\text { height } \\
(\mathrm{m})\end{array}$ & Year & $\begin{array}{l}\text { Con- } \\
\text { tour }\end{array}$ & $\begin{array}{c}\text { Water } \\
\text { depth } \\
\text { (m) }\end{array}$ & $\begin{array}{c}\text { Age } \\
\text { (max.) }\end{array}$ & $\begin{array}{l}\text { yr ) } \\
\text { phys. }\end{array}$ & $1-\mathrm{R}$ & $\mathrm{p}$ & $\begin{array}{c}\text { Gravel } \\
(\%)\end{array}$ & $\begin{array}{c}\text { Fines } \\
(\%)\end{array}$ & Poly. sp \\
\hline \multirow[t]{3}{*}{1403} & \multirow[t]{3}{*}{ Hunter } & \multirow[t]{3}{*}{46} & \multirow[t]{3}{*}{14} & \multirow[t]{3}{*}{4} & \multirow[t]{3}{*}{2} & 91 & $\mathrm{O}$ & 14 & & & & & & & \\
\hline & & & & & & 91 & B & 13 & 1 & $\mathrm{~N}$ & 0.142 & $0.001^{* *}$ & & & \\
\hline & & & & & & 91 & $\mathrm{~T}$ & 15 & 1 & $\mathrm{~N}$ & 0.079 & $0.001^{* *}$ & & & \\
\hline \multirow{2}{*}{1276} & \multirow{2}{*}{ Sal-jr } & \multirow{2}{*}{309} & \multirow{2}{*}{79} & \multirow{2}{*}{12} & \multirow[t]{2}{*}{2} & 95 & B & 16 & ? & $\mathrm{R}$ & 0.238 & $0.001^{* *}$ & & & \\
\hline & & & & & & 95 & $\mathrm{~T}$ & 18 & ? & $\mathrm{R}$ & 0.118 & $0.001^{* *}$ & & & \\
\hline \multirow[t]{2}{*}{0119} & \multirow[t]{2}{*}{ Sal-4 } & \multirow[t]{2}{*}{287} & \multirow[t]{2}{*}{585} & \multirow[t]{2}{*}{50} & \multirow[t]{2}{*}{2} & 95 & B & 26 & ? & $\mathrm{R}$ & 0.274 & $0.001^{* *}$ & & & \\
\hline & & & & & & 95 & $\mathrm{~T}$ & 28 & ? & $\mathrm{R}$ & 0.165 & $0.001^{* *}$ & & & \\
\hline \multirow[t]{6}{*}{0008} & \multirow{6}{*}{ Cutter } & \multirow[t]{6}{*}{282} & \multirow{6}{*}{278} & \multirow[t]{6}{*}{13} & \multirow[t]{6}{*}{5} & 94 & $\mathrm{O}$ & 23 & & & & & 74.26 & 14.51 & \\
\hline & & & & & & 94 & B & 19 & 1 & $\mathrm{~N}$ & 0.082 & $0.001^{* *}$ & 59.53 & 20.95 & \\
\hline & & & & & & 94 & $\mathrm{~T}$ & 24 & 1 & $\mathrm{~N}$ & 0.184 & $0.001^{* *}$ & 43.95 & 43.95 & \\
\hline & & & & & & 95 & $\mathrm{O}$ & 23 & & & & & & & \\
\hline & & & & & & 95 & B & 19 & 2 & $\mathrm{R}$ & 0.121 & $0.001^{* *}$ & & & \\
\hline & & & & & & 95 & $\mathrm{~T}$ & 24 & 2 & $\mathrm{R}$ & 0.176 & $0.001^{* *}$ & & & \\
\hline
\end{tabular}

The sidescan sonar mosaics also enabled location of an area that lacked scours due to an offshore rise. This area was within the sampling region and was similar in aspect, exposure and sediment characteristics to the reference sites in the chronically scoured parts of the region. It was hypothesized that chronic disturbance would influence community composition even where disturbance was sufficiently infrequent to make the seabed appear undisturbed. In 1996, 3 groups of 6replicate samples were taken in each area. All samples were taken where there was no scouring evident.

Scour appearance. At 10 to $30 \mathrm{~m}$ depth, the seabed in Barrow Strait along the coast of Cornwallis Island was a mixed glacial till covered by a cobble veneer. Scouring removed the cobble cover and exposed the underlying clay (Fig. 2), giving the ice scours a white appearance in sidescan images. The glacial till was about $5 \mathrm{~m}$ thick above the underlying bedrock. Barrow Strait had tidal currents at the sediment surface that reached $0.031 \mathrm{~m} \mathrm{~s}^{-1}$ (measured over 1 tidal cycle in August 1994: unpubl. data) and received the full range of scour from small annual ice to large icebergs and multi-year ice keels.

The scours sampled biologically were 14 to $585 \mathrm{~m}$ long and 4 to $50 \mathrm{~m}$ wide, had trough-to-berm heights of 1 to $5 \mathrm{~m}$, and were in water depths of 12 to $28 \mathrm{~m}$ (Table 1). Most originated in the southeast. Sediment
Fig. 2. Sidescan sonar mosaic of ice scours offshore of southern Cornwallis Island near Sight Point in August 1992. Large scours in left-center and rightcenter are recent scours 'Crosscut' and 'Incisor', respectively; smaller scour on far right is new scour 'Lower Molar'; vague impressions of old scours are also visible. Boomerang-shaped scour on far left was not sampled as it was beyond the depth range of this study (map constructed by Canadian Seabed Research Ltd for the Geological Survey of Canada)

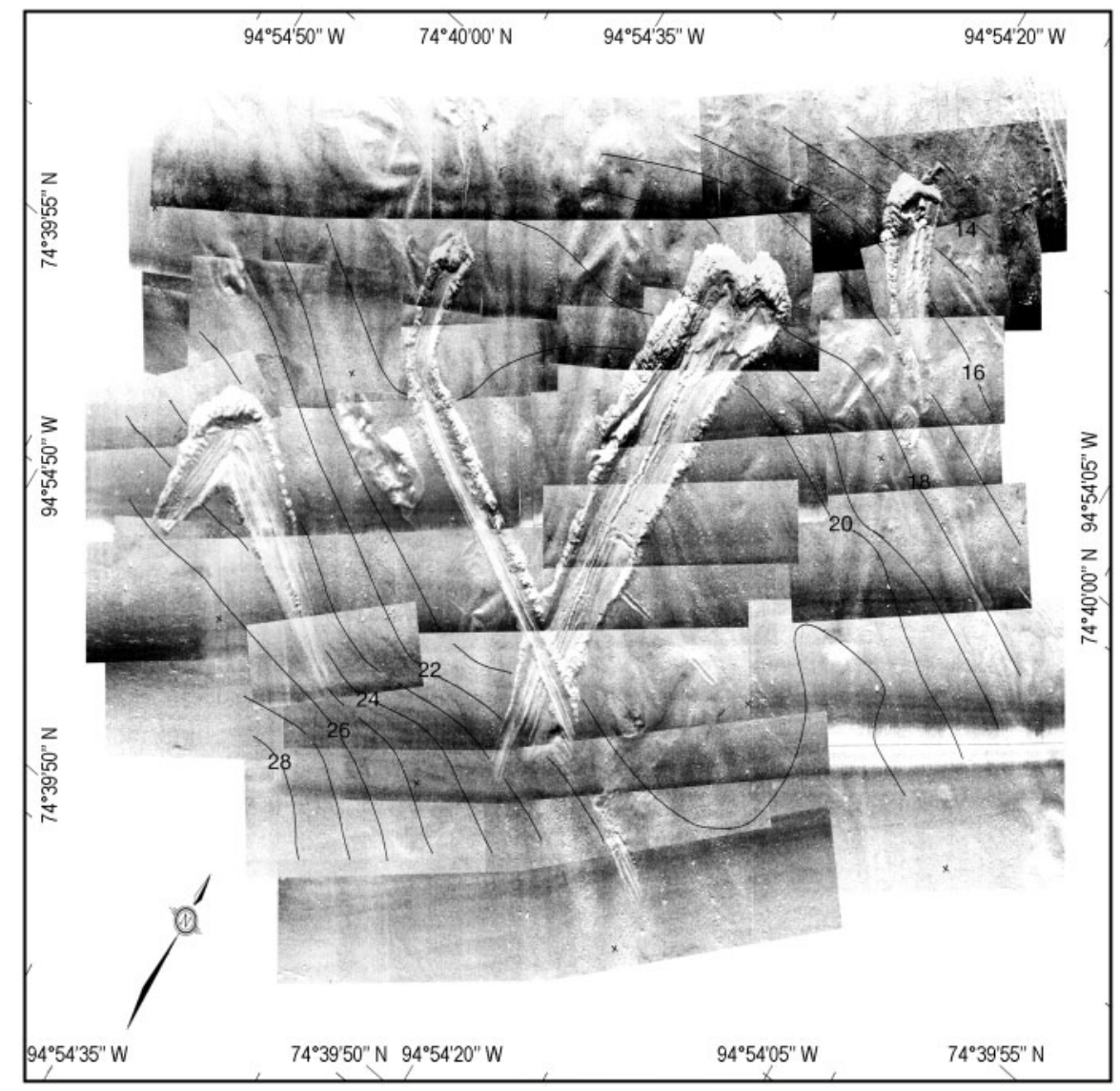


grain size was determined from single surface scrapes (top $5 \mathrm{~cm}$ ) collected at all 1994 sites and contours, using $\%$ dry weight $\geq 4.75 \mathrm{~mm}$ (gravel), $4.75>x \geq 0.075 \mathrm{~mm}$ (sand) and $<0.075$ (fines). Scour dimensions were measured from sidescan mosaics. Scour location was recorded by differential GPS. Water depth and troughberm height were recorded by divers at the location of faunal sampling.

New scours (those formed within the year) had a fresh clay surface. The remains of crushed organisms (such as sea urchins and bivalves) were sometimes visible and gases from the product of biotic decomposition sometimes emanated from the sediment as streams of bubbles. The berms had blocks and peaks of sediment, and the trough and berm edges contained fractures, grooves and other ice impressions at times. Compared to the unscoured sediment, young scours were soft and easily penetrable. A ruler weighted with $10 \mathrm{~kg}$ penetrated the trough sediment of $2 \mathrm{yr}$ old 'Incisor' by $43.3 \pm 1.7 \mathrm{~cm}(\mathrm{n}=3)$ and the berm sediment by $51.7 \pm 3.3 \mathrm{~cm}$ compared to $12.3 \pm 1.4 \mathrm{~cm}(\mathrm{n}=3)$ in the unscoured sediment outside. New scours were probably formed during the winter when large multiyear ice or icebergs were frozen into the polar pack ice and were driven by its force. Diver observations showed that ice drifting in open water in the summer had little force and the incision into the hard packed sediment in Barrow Strait was superficial.

Recent scours were $>1$ to $10 \mathrm{yr}$ old (Blasco et al. 2000). On sidescan images, these scours appeared to consist of freshly scraped clay (unless in the upper agerange), but with diver observation had less sharply contoured berms than new scours and lacked the clear grooving left by an ice keel. Erosion effects were visible in the emergence of cobbles, boulders and shell debris and a more rounded and 'melted' appearance of the formerly sharply defined clay blocks.

Middle-aged scours were subdued in contour, but the berms were clearly raised and visible to divers and also on sidescan images. The berms still had a clay appearance but were interspersed with numerous boulders and cobbles. The trough was nearly totally covered in cobble and shell debris exposed by erosion and tumble-down from the berm. Based on physical appearance, Blasco et al. (2000) estimated that middleaged scours were $>10$ to $20 \mathrm{yr}$ old.

Old scours were estimated to be $>20$ to $50 \mathrm{yr}$ old (Blasco et al. 2000). The troughs were totally armored with cobble and, to divers, were indistinguishable from the unscoured sediment outside. However, the berms were still raised and incompletely armored, and were visible both to divers and to sidescan sonar.

Faunal analysis. The core samples were sieved through $0.5 \mathrm{~mm}$ mesh, fixed in $4 \%$ buffered formalinseawater, and preserved in $70 \%$ glycerated ethanol.
The 6 replicates collected from the new scour 'Flat-top' in 1994 were also washed through $2.5 \mathrm{~mm}$ in order to examine larval settlement. In the laboratory, the fauna were microscopically sorted and identified to the lowest possible taxonomic level, enumerated, and weighed damp-dry. Feeding, burrowing and reproductive characteristics of the fauna were determined from Reid \& Reid (1969), Stanley (1970), Bernard (1979), Fauchald \& Jumars (1979), Barnes (1980), Brusca \& Brusca (1990), Rouse \& Pleijel (2001), Young (2002), E. L. Bousfield (Royal Ontario Museum, pers. comm.), and J. Fournier and A. Martel (Canadian Museum of Nature, pers. comm.). All cores were identified to the lowest possible taxonomic level given available expertise and time. In 1993, the polychaete fraction of the 42 samples collected that year in Barrow Strait was sent to a polychaete taxonomist for full species identification. Unfortunately, 25 of these samples were damaged before identifications could be made. Those samples remaining were identified to species level and are listed in Table 1. The polychaete fraction for the lost samples was estimated as the average abundance in the remaining cores from that site.

Co-occurring macrofauna. The Barrow Strait seabed at $20 \mathrm{~m}$ comprises a sea urchin barrens dominated by Strongylocentrotus droebachiensis and S. pallidus. The only macroalga co-occurring with the sea urchins is the inedible kelp Agarum clathratum (formerly A. cribrosum). The cobble and boulders are coated with the coralline alga Lithothamnion sp. The large burrowing bivalve Mya truncata occurs at up to $140 \mathrm{~m}^{-2}$ (Welch et al. 1992) and accounts for the greatest proportion of biomass in the infauna. The brittle stars Ophiura sarsi, O. robusta, Ophiacantha bidentata, and Ophiocten sericeum are also abundant. Other large, but sparser, invertebrates are the cockle Serripes groenlandicus, the soft coral Gersemia rubiformis, the sea anemones Urticina spp. and Hormathia spp., the sea cucumbers Cucumaria spp. and Psolus spp., the sea stars Crossaster spp., Leptasterias spp. and Solaster spp., solitary tunicates, the shrimp Sclerocrangon boreas, and the large isopod Arcturus baffini. Quantitative analyses of these large organisms will be presented elsewhere. These large organisms may have influenced recolonization of the smaller core-collected fauna. The glacial till contained considerable amounts of shell remains, mainly from the bivalves Mya truncata and Hiatella arctica and tests of the barnacle Balanus crenatus. Young living $B$. crenatus were only present in the absence of sea urchins, suggesting that the invasion of urchins in Barrow Strait may be a geologically recent phenomenon.

Statistical analysis. Multivariate analyses were applied using PRIMER Version 5.2 described in Clarke \& Warwick (2001) and Clarke (1993). Similarity matrices were generated using the Bray-Curtis index. Only 
a moderate square-root transformation was required since abundances differed by no more than 2 orders of magnitude (Clarke \& Warwick (2001). The effect of taxonomic aggregation of the polychaetes was determined by Spearman rank correlation using RELATE, a non-parametric Mantel test.

Community differences among the scours were computed by ANOSIM, a permutation analysis of rank similarities (Clarke \& Green 1988, Clarke 1993). Comparison with the reference communities was based on all reference samples combined $(\mathrm{n}=16)$. Faunal abundances in the 6-replicate cores at each site were averaged for ANOSIM analyses in order to prevent pseudoreplication (Hurlbert 1984). Recolonization rate was computed by change in the ANOSIM R:

$$
\mathrm{R}=\operatorname{avg} \cdot \mathrm{r}_{\mathrm{b}}-\operatorname{avg} \cdot \mathrm{r}_{\mathrm{w}} /(M / 2)
$$

where avg. $\mathrm{r}_{\mathrm{b}}$ is the average of rank similarities between the scour and reference samples, avg. $\mathrm{r}_{\mathrm{w}}$ is the average of rank similarities within the scour and within the reference samples and $M=n(n-1) / 2$. Re-computation of $\mathrm{R}$ upon random rearrangement of sample labels provides a null distribution of $\mathrm{R}$ values from which the significance of the $\mathrm{R}$ value for the original community matrix can be determined. The use of the ANOSIM R to determine community recolonization was first suggested by Philippi et al. (1998) but has not been widely used since. $R$ values are presented as $1-R$ so that plots rise, reflecting increasing similarity of the scours to the reference sites over time.

Non-metric multidimensional scaling (MDS) was applied to examine scour intensity effects. We removed 1 outlier for the non-chronically scoured area from the analysis because this sample was sufficiently depauperate to force all other samples to cluster tightly and mask differences among them. The outlier was also removed from subsequent calculations of abundance, biomass and diversity in order to make conclusions more conservative. Significant differences between the communities were determined by 1-way ANOSIM.

The scours selected for biological study differed in location, orientation, dimensions, and year of sampling, water depth, apparent physical age and sediment grain size (Table 1). To determine what non-biological variables best grouped the scours in a manner consistent with the biological distribution patterns, the similarity matrix produced by the nonbiological variables $(\mathrm{n}=11$ ) was correlated with the biological similarity matrix ( $\mathrm{n}=64$, all scours and years, replicates averaged) using a Spearman rank correlation coefficient, no transformation (BIOENV procedure, Clarke \& Ainsworth 1993). Reference samples $(n=16$, repli- cates averaged) were analyzed with 3 of these (other variables relevant only to scours did not apply; insufficient data for grain size).

Taxa that dominated the scour (berm and trough combined) and reference communities were determined by similarity percentages (SIMPER), using standardized and double square-root-transformed abundances. Taxa that cumulatively contributed $75 \%$ of the average within-group similarity were considered to comprise the dominants. Early colonizers of scours were those whose abundance in the young scour community was greater or equal to abundance in the reference community $(p<0.05)$. The young scour community was arbitrarily defined as that with 1 -ANOSIM $\mathrm{R}$ $\leq 0.2$, which was a quarter of the way to achieving completion of recolonization (assuming a linear function). When 1-ANOSIM R $>0.8$, the scour community was no longer significantly different from the reference community $(p<0.05)$ (Table 1$)$. Later colonizers were those with significantly lower abundance in the young scour community than in the reference community. Because of a high frequency of absences in the samples, the abundance of many of the taxa was not normally distributed, even after $\log _{10}$-transformation. A similar lack of normality was found before and after $\log _{10}$-transformation of 1 -ANOSIM R fractions of total community abundance, biomass and diversity. Accordingly, means comparisons were made by a MannWhitney 2-sample rank test computed on SPSS Version 12.0. Regressions were applied using SPSS 12.0.

Community age estimates. Ages of the communities described by 1 -ANOSIM $\mathrm{R}$ values could be determined if they came from known-age scours. Thus, for $1-\mathrm{ANOSIM} \mathrm{R} \leq 0.2$, all 20 of the scours comprising this group were of known age, with a calculated community age of $2.2 \pm 0.3 \mathrm{yr}$ (Table 2 ). For $1-\mathrm{ANOSIM} \mathrm{R}=$ 0.2 to $0.4,3$ of the 25 scours in this $\mathrm{R}$ group were of unknown age and were physically classified as middle- or old-aged. Thus, a community age estimate of $3.7 \pm 0.4 \mathrm{yr}$ based on the remaining 22 known-age scours is probably slightly underestimated. For 1 -ANOSIM $\mathrm{R}=0.4$ to $0.6,2$ of the 6 scours in this $\mathrm{R}$ group were of unknown age; one was physically clas-
Table 2. State of recolonization (mean $\pm \mathrm{SE}$ ) of scours in Table 1 relative to reference samples as measured by Clarke's ANOSIM R

\begin{tabular}{|lccccc|}
\hline $\begin{array}{l}\text { ANOSIM } \\
1-\mathrm{R} \text { group }\end{array}$ & $\mathrm{n}$ & $1-\mathrm{R}$ & $\mathrm{p}$ & Age & $\begin{array}{c}\text { \% known } \\
\text { age }\end{array}$ \\
\hline $0-0.2$ & 20 & $0.103 \pm 0.001$ & $0.001 \pm 0$ & $2.15 \pm 0.34$ & 100 \\
$0.2-0.4$ & 25 & $0.288 \pm 0.011$ & $0.001 \pm 0$ & $3.68 \pm 0.39$ & 88 \\
$0.4-0.6$ & 6 & $0.540 \pm 0.013$ & $0.003 \pm 0.001$ & $7.75 \pm 1.74$ & 66.6 \\
$0.6-0.8$ & 6 & $0.685 \pm 0.026$ & $0.043 \pm 0.025$ & $?$ & 16.7 \\
$0.8-1.0$ & 4 & $0.950 \pm 0.028$ & $0.331 \pm 0.064$ & $?$ & 0 \\
$1.0-1.2$ & 3 & $1.099 \pm 0.042$ & $0.770 \pm 0.098$ & $?$ & 0 \\
\hline
\end{tabular}


sified as middle-aged and the other as old-aged. Thus, a community age estimate of $7.8 \pm 1.7 \mathrm{yr}$ based on the remaining 4 known-age scours is probably even more of an underestimate than for the previous 1-R category because one-third of the scours in the group were of unknown age. Ages of the scours in the higher 1-R groups were all unknown, making it impossible to estimate the ages of the communities. For the purpose of presentation, the communities in the $1-\mathrm{R}$ fractions were given the ages 2,4 , and 9 for the 0 to $0.2,0.2$ to 0.4 , and 0.4 to 0.6 fractions, recognizing that a source of error is the lack of knowledge of the age of all scours. Another source of variation is the actual time within the year that scouring occurred, making it meaningless to give an estimate to a decimal place.

\section{RESULTS}

\section{Taxonomic aggregation}

A total of 129 taxa were identified. Because of the large number of specimens collected (about 95000 ) it was not possible to identify all specimens to species level. Polychaetes accounted for an average $37.5 \pm$ $5.4 \%$ of faunal abundance in these samples. Similarity matrices were produced for the 17 cores with polychaetes identified to species (Table 1) and again when they were aggregated to family. Data for nonpolychaete taxa were also added. The Spearman rank correlation for the 2 similarity matrices was 0.783 , $\mathrm{p}=0.001$. This indicates that the sample relationships were largely retained when the polychaetes were aggregated to the family level. Warwick (1988), Somerfield \& Clarke (1995), Chapman (1998), Thompson et al. (2003), and De Biasi et al. (2004) also found no substantial loss of information at coarser levels of taxonomic resolution when describing patterns in the marine benthos. Dauvin et al. (2003) cite 35 papers that have dealt with this subject since 1985 and they conclude that fast, cost-effective and accurate pollution monitoring can be obtained with family-level identifications for sublittoral benthic communities.

\section{Environmental influences}

Table 3 shows the highest correlations with faunal composition found for the 11 physical variables. Faunal pattern was more highly correlated with estimated physical age of the scour than with any other variable singly or combined (Spearman rank correlation $=0.576$ ). Sediment grain size and water depth, and scour location, orientation, dimensions and contour had much lower correlations $(-0.083$ to 0.189$)$. Year of sampling
Table 3. Spearman rank correlations of environmental factors with faunal composition in all scours and unscoured reference (Ref.) samples listed in Table 1. NA: not applicable; ID: insufficient data

\begin{tabular}{|lcc|}
\hline Variable & Scours & Ref. samples \\
\hline Physical age group & 0.576 & NA \\
Trough to berm height & 0.189 & NA \\
Scour length & 0.188 & NA \\
Scour width & 0.176 & NA \\
Location & 0.173 & 0.611 \\
Year & 0.116 & 0.084 \\
$\%$ gravel & -0.083 & ID \\
Scour orientation & 0.044 & NA \\
$\%$ fines & 0.033 & ID \\
Water depth & 0.005 & 0.252 \\
Contour & -0.003 & NA \\
\hline
\end{tabular}

also had a low correlation (0.116), justifying grouping of scours in other analyses. Faunal patterns in the unscoured reference samples correlated most highly with location along the coast (0.611). Water depth (0.252) and year of sampling (0.084) showed much lower correlations.

\section{Recolonization rate}

The state of community recolonization of the scours, as estimated by ANOSIM 1-R, is shown in Table 1 and summarized in Table 2 . The scour communities were significantly different from reference until ANOSIM $1-\mathrm{R}>0.8$. Scours with sufficient time series ('Lower Molar' and 'Incisor') showed a linear increase in resemblance with the unscoured reference community over time (Fig. 3). Highest resemblance was in the 'Lower Molar' trough at Age 8, but this still differed significantly in composition from the unscoured reference community $(p<0.05)$ (Table 1$)$. Some setbacks occurred for 'Lower Molar' and 'Incisor' between Ages 3 and 5. Assuming that further colonization would continue to be linear, recolonization was $84 \%$ complete (no longer significantly different from reference) in the trough and $66 \%$ complete in the berm of 'Lower Molar' at Age 8. For 'Incisor', last sampled at Age 9, recolonization was 65 and $74 \%$ complete. The 'Groovy' trough was the slowest of the scour troughs to recolonize when young and the berm advanced much more quickly. ANOSIM 1-R values for troughs and berms were significantly correlated (Pearson correlation = 0.757, $\mathrm{p}=0$ ), indicating that the species composition of the colonizing communities was similar in the 2 contours. ANOSIM 1-R values also correlated significantly with physical estimates of the scour ages (Pearson correlation $=0.746, \mathrm{p}=0$ for troughs and $0.775, \mathrm{p}=$ 0 for berms). 


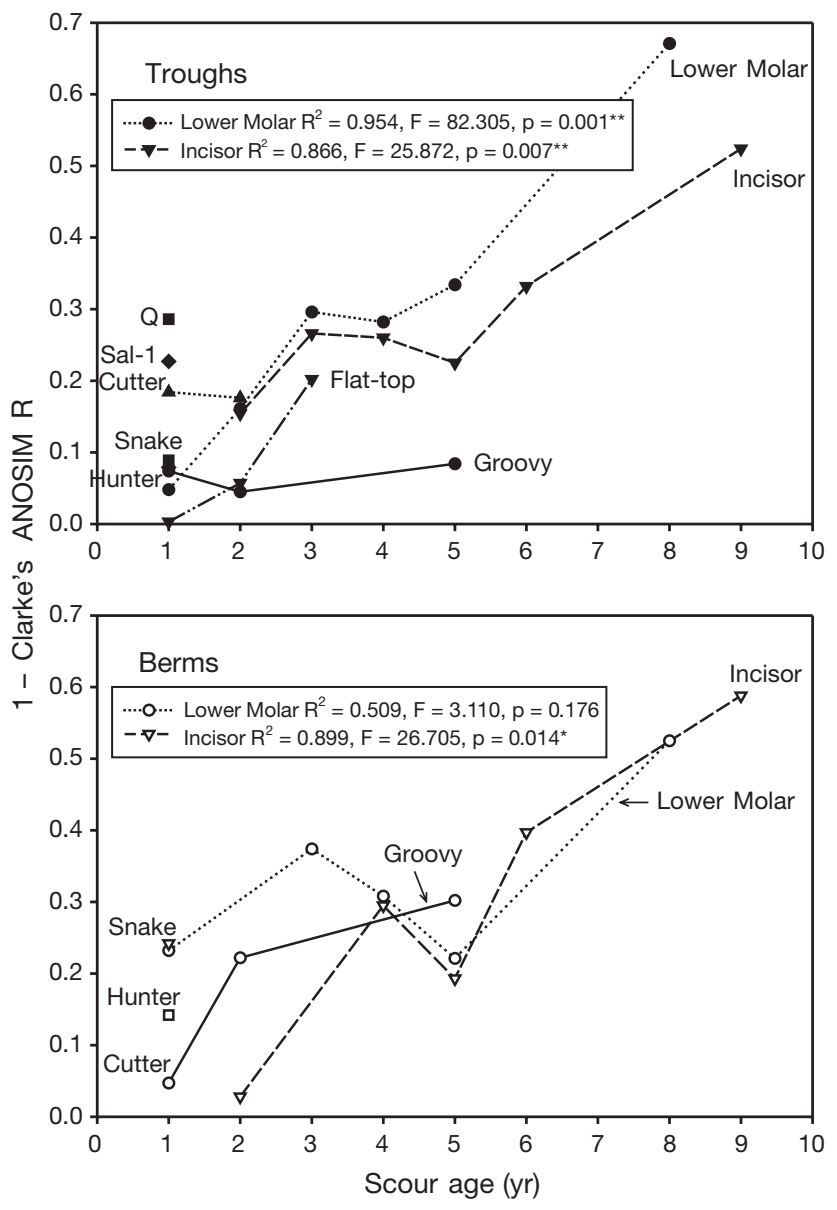

Fig. 3. Recolonization of known-age scours using Clarke's ANOSIM $R$, a measure of resemblance to the reference community. Scour details in Table 1. *: p < 0.05; **: $p<0.01$

\section{Changes in abundance, biomass and diversity over time}

Community abundance, biomass, species richness and taxonomic diversity increased significantly as the scours were recolonized (Fig. 4). Only evenness did not increase significantly over time. All variables in the trough communities correlated significantly with the berms. Spearman rank correlation between trough and berm $(\mathrm{n}=27)$ for abundance was $0.46, \mathrm{p}=0.002$; for biomass $0.69, p=0$; for richness $0.80, p=0$; for evenness $0.49, \mathrm{p}=0.1$; and for taxonomic diversity $0.61, \mathrm{p}=0.001$.

Abundance of the reference community ranged widely among the samples, from $45.3 \pm 3.8$ to $307.2 \pm$ 43.6 individuals core ${ }^{-1}$. Abundance in the 0 to $4 \mathrm{yr}$ old communities ( $1-\mathrm{R}=0$ to 0.4 , Table 1 ) was significantly lower than in the reference communities (Fig. 4) but not significantly different after this age; 1 old scour berm ('Old Timer') exceeded all others in abundance due to large numbers of bivalves, ostracods and paraonid polychaetes being present. However, no other scours exceeded the range of abundance found in the reference communities.

Biomass was significantly lower than reference biomass in the 0 to $4 \mathrm{yr}$ old scours $(1-\mathrm{R}<0.4)$, but increased to $8.7 \pm 1.5 \mathrm{~g}$ in the $9 \mathrm{yr}$ old scour 'Incisor' because of the regular presence of the bivalves $M y a$ truncata, Serripes groenlandicus, Musculus spp. and Hiatella arctica. The variable biomass in the completely recolonized scours (those with $1-\mathrm{R}>0.8$ ) and reference samples was also due to the variable capture of bivalves, particularly the large $M$. truncata and S. groenlandicus.

Species richness in the reference sites ranged from $16.2 \pm 1.4$ to $35.7 \pm 1.5$ taxa core $^{-1}$. Species richness increased rapidly in most young scours, achieving reference levels by $4 \mathrm{yr}(1-\mathrm{R}>0.4)$. As with abundance, the aberrant 'Old Timer' berm samples had significantly greater species richness than reference samples (Fig. 4), but there was no other peak exceeding reference conditions.

Scours of all ages exhibited comparable species evenness (slope $=0.004 \pm 0.040 \mathrm{R}$ evenness ${ }^{-1}$ ). The large intercept $(0.783 \pm 0.019$ evenness $)$ indicates that new colonists did not overly dominate at any time during recolonization. Like species richness, taxonomic diversity reached reference levels after the scours were $4 \mathrm{yr}$ old $(1-\mathrm{R}>0.4)$. The high intercept $(67.7 \pm$ 1.66 taxonomic diversity) indicates that the new colonists were from a variety of taxa that were not closely related.

\section{Dominant taxa}

Of the 129 taxa, 22 dominated the scours or reference samples in abundance; 10 of these were early colonizers (Fig. 5). Cumaceans and capitellid polychaetes were significantly more abundant in the young scour community than in the reference community. The dorvilleid polychaete Ophyrotrocha spatula was particularly restricted to young scours. The abundance of the oedicerotid amphipods Monoculodes spp., hesionid, phyllodocid and spionid polychaetes, ophiuroids, and juvenile bivalves (including Serripes groenlandicus and others that were unidentifiable when small) was as great as in the reference communities (i.e. not significantly different, Mann-Whitney $U$-test, $\mathrm{p}<0.05)$.

Fig. 6 shows the taxa that were later colonizers, being significantly less abundant in the young scour community than in the reference community. Regressions of $\log _{10}$ abundance on $1-\mathrm{R}$ showed significant increases in abundance as the communities aged for the bivalves Lyonsia arenosa, Macoma spp., Musculus spp. and Serripes groenlandicus, cirratulid, paranoid, 

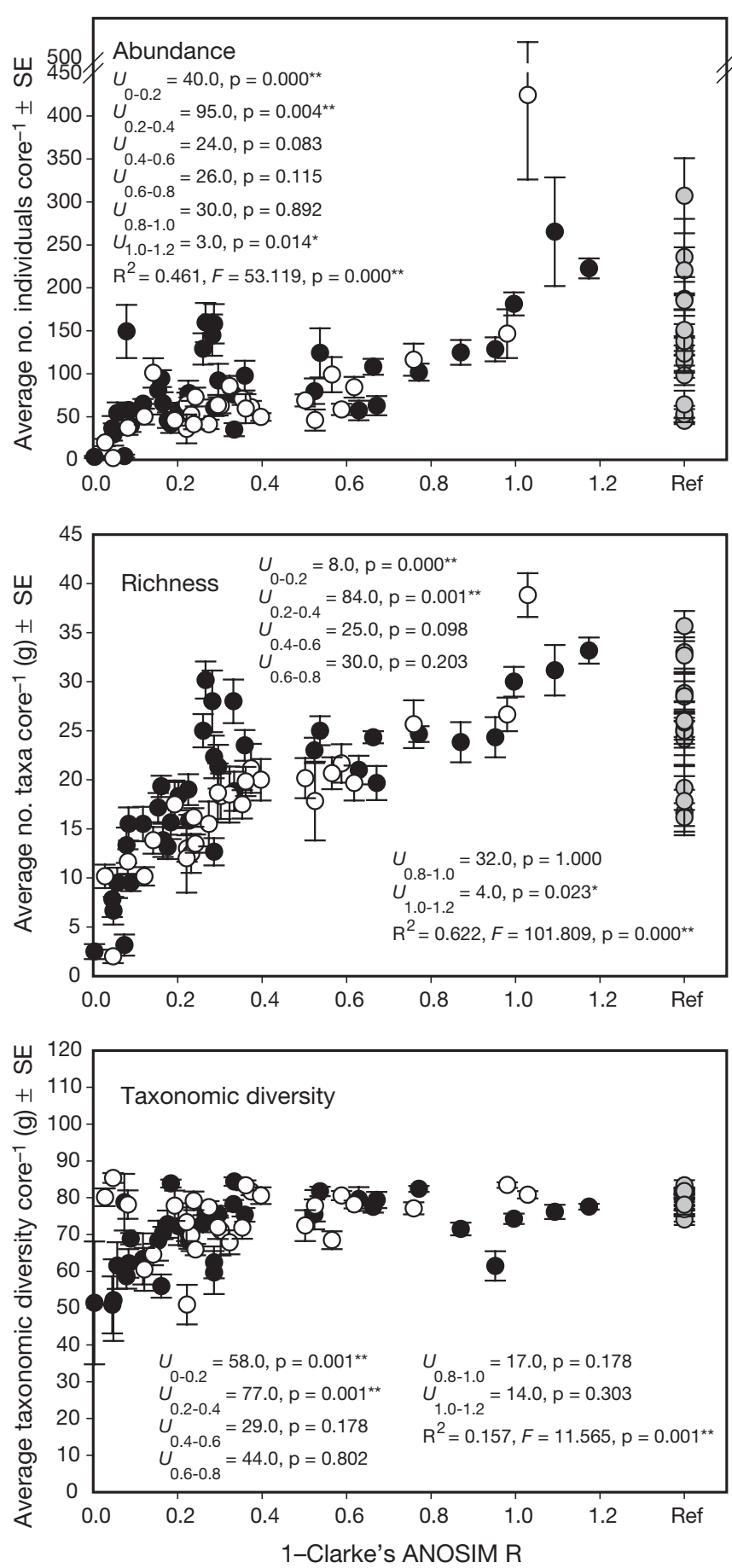

pholoid and ampharetid polychaetes, the gastropod Cingula spp., and ostracod and tanaid crustaceans (Figs. 5 \& 6). Nemerteans and ampharetid and pholoid polychaetes were present in variable numbers throughout recolonization. The large bivalve Mya truncata was not captured frequently enough to be considered a dominant species, but this was because it was a deep burrower and out of the range of the corer,
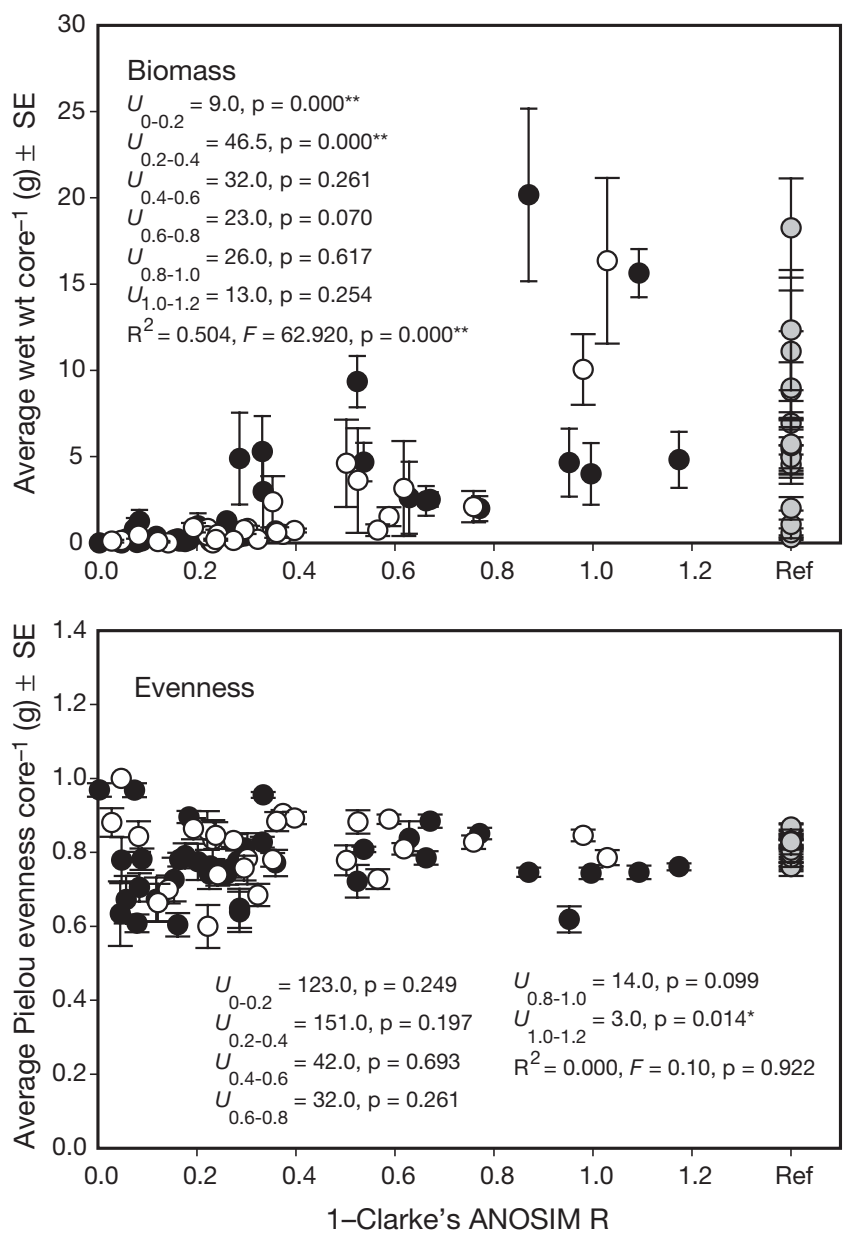

Trough $\bigcirc$ Berm $\bigcirc$ Reference

Fig. 4. Average abundance, biomass, and diversity in scour and reference communities plotted according to state of recolonization (based on Clarke's ANOSIM R). Mann-Whitney $U$-test and 2-tailed probabilities for comparison of means between reference $(n=16)$ and scour communities at progressive $\mathrm{R}$ intervals of $0.2(\mathrm{n}=20,25,6,6,4$, and 3). Linear regressions calculated on untransformed means. ${ }^{*}$ : $\mathrm{p}<0.05$; ${ }^{* *}: \mathrm{p}<0.01$

especially when larger. It too was common in undisturbed sediment. Only Ophryotrocha spatula was clearly less abundant in older communities (Fig. 5), although due to its patchiness in the young scours this trend was marginally not significant $(p=0.52)$. Thus, most early colonizers maintained their abundance as the scours aged, even while late colonizers were significantly increasing in abundance. 

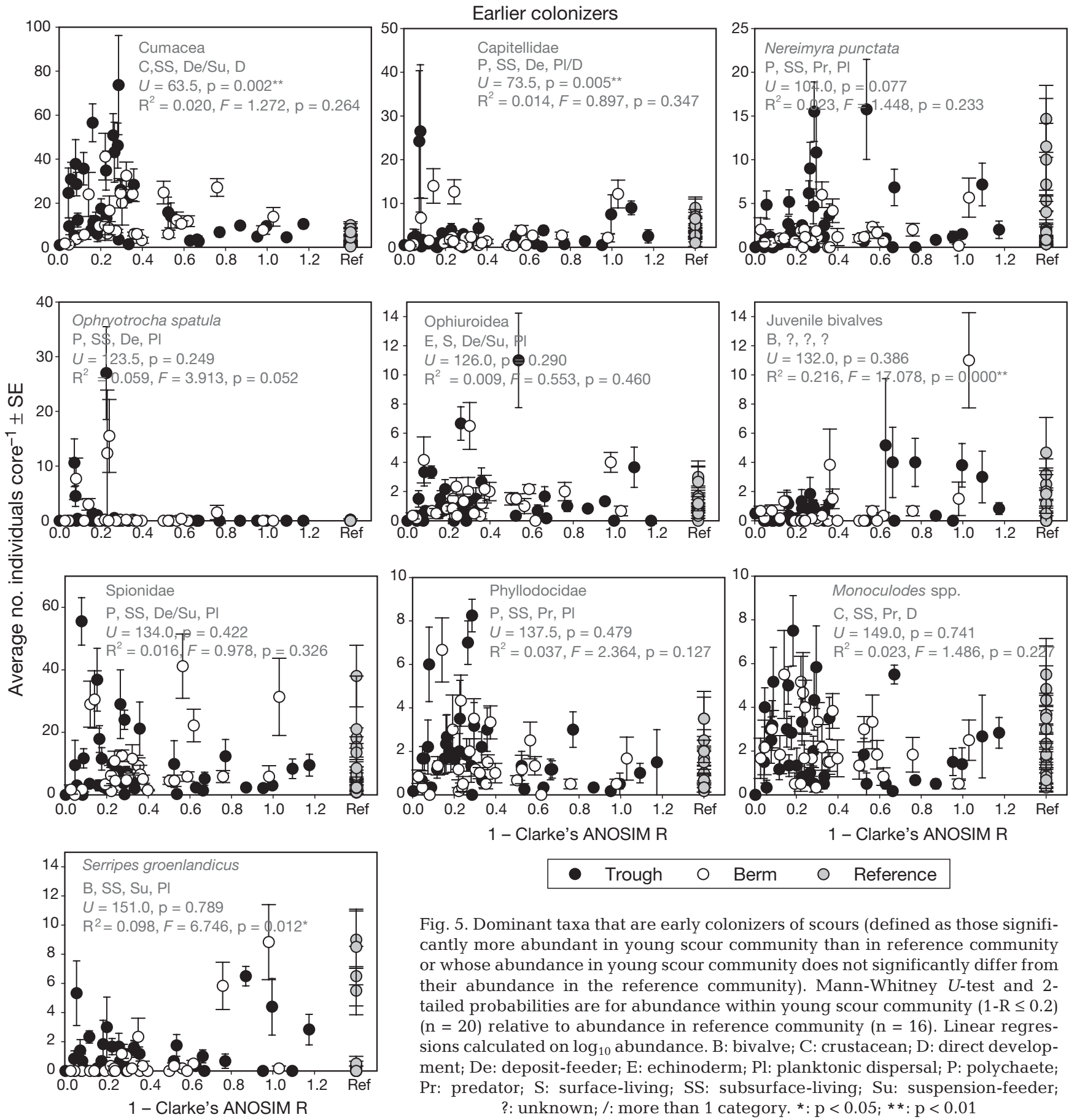

\begin{tabular}{lllll|}
\hline - Trough & Berm $\bigcirc$ & Reference \\
\hline
\end{tabular}

Fig. 5. Dominant taxa that are early colonizers of scours (defined as those significantly more abundant in young scour community than in reference community or whose abundance in young scour community does not significantly differ from their abundance in the reference community). Mann-Whitney $U$-test and 2tailed probabilities are for abundance within young scour community $(1-\mathrm{R} \leq 0.2)$ $(n=20)$ relative to abundance in reference community $(n=16)$. Linear regressions calculated on $\log _{10}$ abundance. B: bivalve; C: crustacean; D: direct development; De: deposit-feeder; E: echinoderm; Pl: planktonic dispersal; P: polychaete; Pr: predator; S: surface-living; SS: subsurface-living; Su: suspension-feeder; ?: unknown; /: more than 1 category. ${ }^{*}$ : $\mathrm{p}<0.05 ;{ }^{*}$ : $\mathrm{p}<0.01$

Figs. $5 \& 6$ also show the taxonomic, feeding and dispersal characteristics of the dominant early and later colonizers, and these are summarized in Table 4. Taxonomic composition was similar in the 2 groups (Spearman rank correlation, $p=0.047$ ). Most were polychaetes, crustaceans or bivalves. Burrowing characteristics were not significantly correlated between the groups $(p=0.866)$, with more of the early coloniz- ers living below the surface while a greater proportion of later colonizers lived primarily on the surface. Most of the colonists were deposit- or suspension-feeders or varied their feeding modes between the two. There was a larger proportion of suspension-feeders and fewer predators among the later colonizers, however. There were too many unknowns for larval development to draw conclusions on differences. 

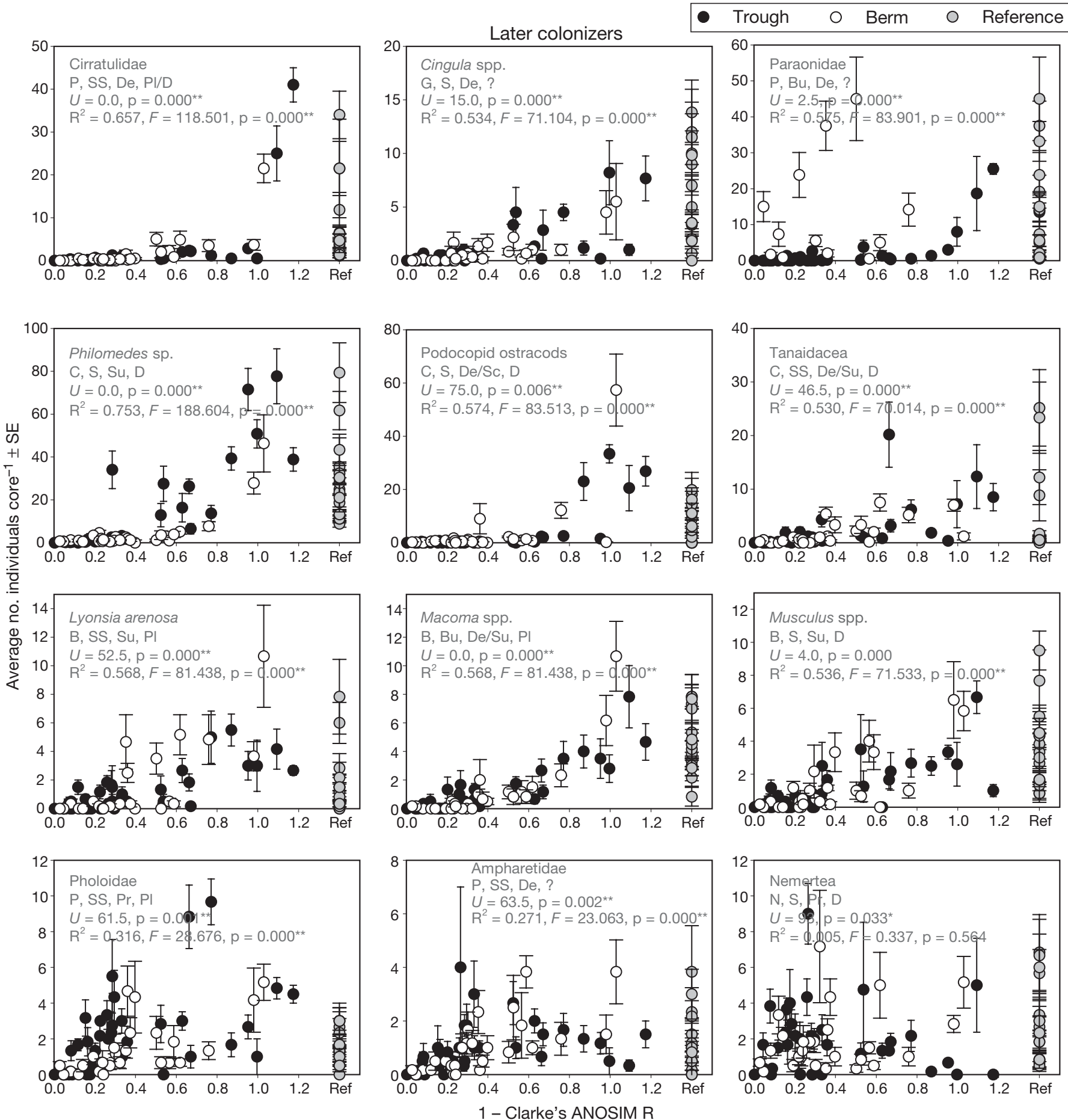

Fig. 6. Dominant taxa that are later colonizers of scours (defined as those significantly less abundant in young scour community than in the reference community). Bu: burrower; G: gastropod; N: nemertean; Sc: scavenger; other abbreviations as in Fig. 5

\section{Unusual scour features}

Raised scour. The scour 'Flat-top' (Table 1) was a rescour of the berm of the scour 'Incisor'. Therefore, unlike the other scours, it had been formed from an existing scour rather than from unscoured sediment. 'Flat-top' also differed in that its trough was not a sediment incision surrounded by berms but a raised berm flattened by grazing ice. Fig. 3 shows that the Year 1 community in 'Flat-top' had low resemblance to the 
Table 4. Characteristics of dominant 10 early colonizers and 12 later colonizers of ice scours. Spearman: Spearman rank correlation coefficient. ${ }^{*} p<0.05$

\begin{tabular}{|lcccccc|}
\hline Category & $\begin{array}{c}\text { Early } \\
(\%)\end{array}$ & $\begin{array}{c}\text { Later } \\
(\%)\end{array}$ & Spearman & $\mathrm{p}$ & $\mathrm{n}$ \\
\hline Taxon & & & & & \\
Nemertean & 0 & 8.3 & 0.818 & $0.047^{*}$ & 6 \\
Polychaete & 50 & 33.3 & & & \\
Crustacean & 20 & 25 & & & \\
Bivalve & 20 & 25 & & & \\
Gastropod & 0 & 8.3 & & & \\
Echinoderm & 10 & 0 & & & \\
Distribution & & & & & \\
Surface & 10 & 41.7 & 0.866 & 0.333 & 3 \\
Subsurface & 80 & 41.7 & & & \\
Burrower & 0 & 16.7 & & & \\
Unknown & 10 & 0 & & & \\
Feeding & & & & & \\
Deposit & 20 & 33.3 & 0.358 & 0.486 & 6 \\
Suspension & 10 & 25 & & & \\
Deposit or suspension & 30 & 16.7 & & & \\
Deposit or scavenger & 0 & 8.3 & & & \\
Predator & 30 & 16.7 & & & \\
Unknown & 10 & 0 & & & \\
Larval development & & & & & \\
Planktonic & 60 & 25 & 0.5 & 0.667 & 3 \\
Planktonic or direct & 10 & 16.7 & & & \\
Direct & 20 & 33.3 & & & \\
Unknown & 10 & 25 & & & \\
& & & & & \\
\hline
\end{tabular}

reference communities, as measured by ANOSIM R. Species richness was also low, with only $2.50 \pm 0.76$ taxa core ${ }^{-1}$ in its first year and $9.50 \pm 1.54$ taxa core $^{-1}$ in its second. In other 1 yr old scours, species richness was as high as $22.3 \pm 0.85$ taxa core ${ }^{-1}$. Most new scours were typified by abundant early colonizers $\geq 0.5 \mathrm{~mm}$, such as cumaceans, the amphipod Monoculodes spp., the polychaetes Capitella cf. capitata and Nereimyra punctata, and polychaetes in the families Spionidae and Phyllodocidae (Fig. 5). Although cumaceans and capitellids of this size were present in small numbers in 'Flat-top', it lacked Monoculodes spp., N. punctata and spionid polychaetes. However, the $0.25 \mathrm{~mm}$ fraction indicated that the spionid polychaetes Spio filicornis, the hesionid polychaete $N$. punctata, the dorvilleid polychaete Ophryotrocha spatula and the paraonid polychaete Aricidea sp. were indeed present, but as larvae. In the second year, colonization was still less than in most other 2 yr old scours, but within the range of 'Groovy', which was also slow to be colonized (Fig. 3). However, in its third year, the 'Flat-top' community had approached that in the other scours. Thus, contour differences may initially slow faunal colonization, but the effect is not long-term.

Multi-keeled scour. The other unusual scour was 'Groovy', which was a multi-keeled scour rather than a simple incision created by a single ice keel. Groovy consisted of 4 troughs and 5 berms running in parallel. Because the outside trough was simply a shallow graze and the outside berm consequently small, sampling was done in the second trough and on the second berm. The second trough and berm physically resembled troughs and berms of other scours of that age. However, the samples from 'Groovy' differed from those of single-track scours in being separated from the unscoured sediment by an additional trough and berm. Like 'Flat-top', fauna in the 'Groovy' trough and berm showed low species richness $(3.17 \pm 1.08$ and $2.00 \pm 0.68$ individuals core ${ }^{-1}$, respectively) compared to up to $22.3 \pm 0.85$ in the troughs and $13.50 \pm 0.92$ in the berms of other $1 \mathrm{yr}$ old scours. While some scourassociates were present in 'Groovy' (the amphipods Monoculodes spp., cumaceans, and the polychaete Nereimyra punctata), others were rare or absent (the polychaete Ophryotrocha spatula and various other polychaetes in the Spionidae, Capitellidae and Phyllodocidae). 'Groovy' began to be formed in September 1994 and the scour was completed 2 mo later (S. Blasco, Geological Survey of Canada, pers. comm.). Therefore, seemingly there was adequate time for colonization during the spring reproductive pulse in 1995 before sampling occurred in August 1995. Species composition and diversity still lagged in Year 2 in both troughs and berms. By Year 5, species composition had caught up.

Fractures as distinct settling environments. 'Groovy' was also unique in having several fractures in the trough which had been created by sediment stress as the ice keel ploughed through the sediment. These fractures measured about $1 \mathrm{~m}$ wide and $0.5 \mathrm{~m}$ deep, and 9 mo following scouring, they were densely packed with filamentous diatoms (Parlibellus sp.). Numerous harpacticoid copepods and nematodes inhabited the mass of diatom threads. This diatom mat was present in the scour troughs and berms also, but not in such high density.

A 1-way ANOSIM indicated that the fractures did not differ significantly from each other in faunal composition (Table 5). Fracture 1 differed significantly from the trough and berm communities immediately

Table 5. Results of 1-way ANOSIM R pairwise comparisons of community composition in fractures, trough and berm of scour 'Groovy' in 1996. ${ }^{*} \mathrm{p}<0.05$

\begin{tabular}{|lccc|}
\hline Pairwise comparison & $\mathrm{R}$ & No. permutations & $\mathrm{p}$ \\
\hline Fracture 1 vs Fracture 2 & 1.000 & 3 & 0.333 \\
Fracture 1 vs Trough & 0.521 & 28 & $0.036^{*}$ \\
Fracture 1 vs Berm & 0.656 & 28 & $0.036^{*}$ \\
Fracture 2 vs Trough & 0.323 & 28 & 0.143 \\
Fracture 2 vs Berm & 0.479 & 28 & 0.071 \\
Trough vs berm & 0.244 & 462 & $0.037^{*}$ \\
\hline
\end{tabular}


outside the fractures $(p<0.05)$, but differences for Fracture 2 were not significant. All scour samples differed significantly from reference samples taken outside the scour. Compared to the trough, Fracture 1 supported much higher numbers of capitellid (168.50 \pm 73.50 vs $2.17 \pm 1.97$ core $\left.^{-1}\right)$, hesionid $(25.50 \pm 7.50$ vs 0 core $\left.^{-1}\right)$, and dorvilleid $\left(20.50 \pm 14.50\right.$ vs 0 core $\left.^{-1}\right)$ polychaetes, numerous myodocopid ostracods $(14.50 \pm 7.50$ vs $0.50 \pm 0.22$ core $\left.^{-1}\right)$, and cumaceans $(17.50 \pm 14.50$ vs $24.67 \pm 11.33 \mathrm{core}^{-1}$ ). Fracture 2 supported similar fauna but not in such high densities as Fracture 1.

\section{Scour-intensity effects}

The community in the chronically scoured area of Barrow Strait differed significantly from the community in the non-chronically scoured area protected from scouring by an offshore rise (1-way ANOSIM, R = $0.348, \mathrm{p}=0.001,999$ permutations). MDS ordination demonstrated this distinctiveness (Fig. 7). A BIOENV analysis showed that location correlated more highly with community variation (Spearman rank-correlation $r=0.684)$ than did differences in water depth (16 to $21 \mathrm{~m})(\mathrm{r}=-0.370)$. Species richness was significantly higher in the area subject to chronic scour than in the area protected from ice disturbance $(2$-tailed $t$-test $=$ 2.60, $\mathrm{p}=0.014, \mathrm{df}=33$, Levene's test for equality of variances, $F=5.44, \mathrm{p}=0.026$ ). There was no significant difference in evenness or taxonomic diversity of the fauna in the 2 areas.

Our results showed that 19 taxa accounted for $50 \%$ of the dissimilarity between the areas protected from and prone to disturbance. Taxa associated with disturbance comprised a component of the distinguishing species (cumaceans, the amphipods Monoculodes
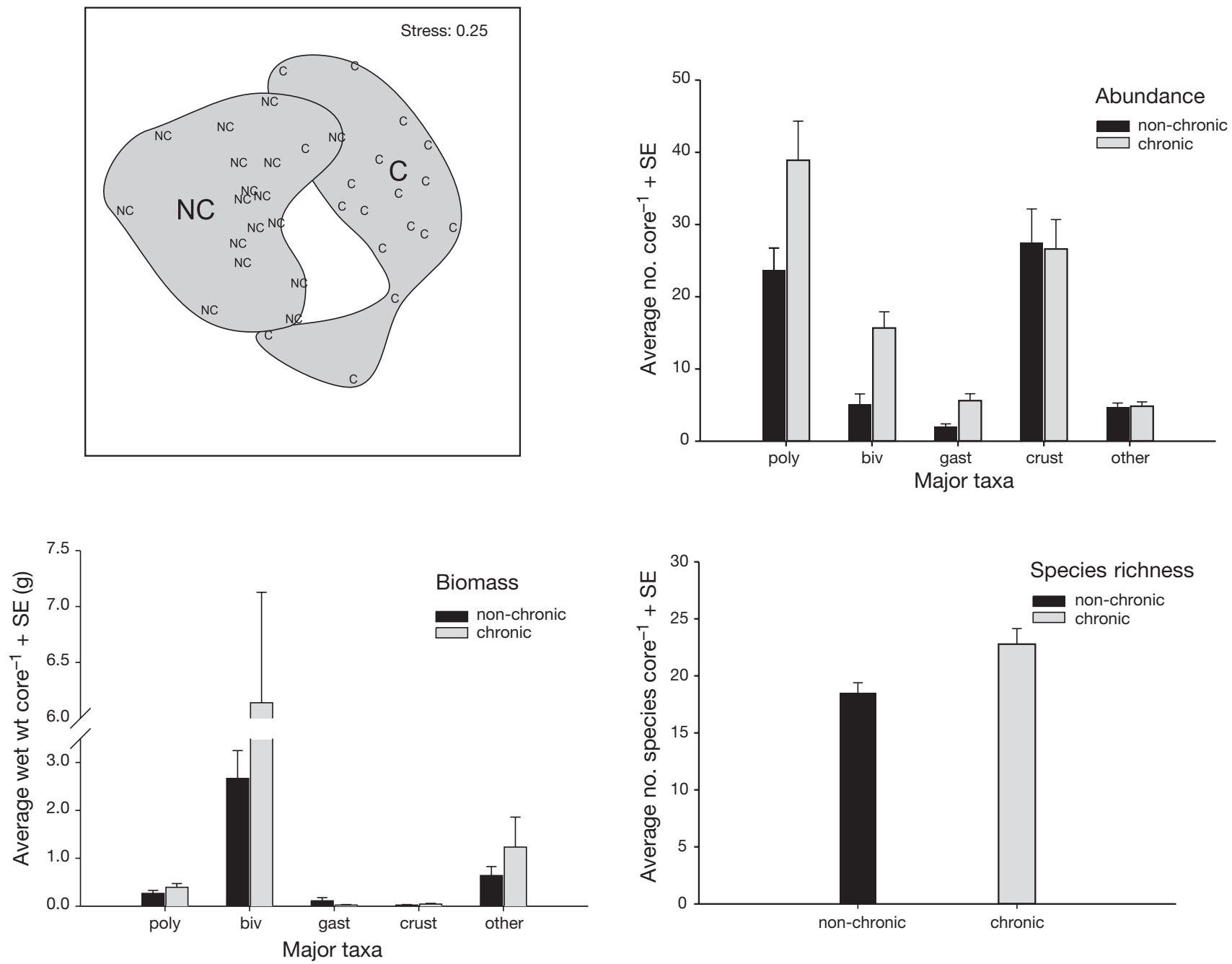

Fig. 7. MDS, abundance, biomass and species richness of fauna in chronically (C) and non-chronically (NC) scoured reference sites in Barrow Strait. poly: polychaetes; biv: bivalves; gast: gastropods; crust: crustaceans 
spp., and spionid and hesionid polychaetes). The other component of the group comprised species associated with less disturbed conditions, such as a number of bivalves (species of the genera Serripes, Mya, Macoma, Astarte and Hiatella), the gastropods Onoba mighelsi and Margarites sp., tanaids, ophiuroids and nemerteans, and a number of polychaetes (paraonids, pholoids, sabellids, ampharetids and trichobranchids). Most of these were present in both areas, but were more abundant in the chronically scoured area than in the rarely scoured area. Indeed, total abundance averaged $91.6 \pm 10.6$ individuals core $^{-1}$ compared to $66.1 \pm 7.6$ individuals core $^{-1}$ in the non-chronically scoured area. Polychaetes, bivalves, and gastropods were nearly twice as abundant in the chronically scoured area as in the protected area (Fig. 7). Biomass, particularly of the bivalves, was also higher in the chronically scoured area. Of the 14 taxa that typified the chronically scoured area and 11 that typified the non-chronically scoured area, 7 were common to both. Thus, although both areas had dominants in common, the chronically scoured area differed from the area not subject to ice disturbance by supporting a community that was more species-rich, abundant, and massive.

\section{DISCUSSION}

The seabed along the coast of Cornwallis Island to $30 \mathrm{~m}$ depth is a mosaic of ice scour disturbances at various stages of recolonization. The benthic community in the undisturbed sediment is a diverse mix of taxa and trophic levels, both burrowing in the clay underlayer and attached to or moving on the overlying cobble (Fig. 8). We report here on the smaller macrofauna captured in $0.0075 \mathrm{~m}^{2}$ cores from 19 scours, 7 of which were repeat-sampled.

Clarke's ANOSIM (Clarke 1993), a multivariate form of analysis of variance, is a useful method of statistically comparing community composition. Philippi et al. (1998) first pointed out that ANOSIM could also be used as a measure of community change. In this study, once ANOSIM 1-R values had exceeded 0.8, the scour community had completed recolonization (i.e. was no longer significantly different from the reference community at $\mathrm{p}<0.5) ; 2$ scours classified by physical criteria as middle-aged ('Elbow' and 'Foot troughs') and 6 classified as old ('Dim', 'Long' and 'Old Timer' troughs and berms) were completely recolonized by this criterion (Table 1). Thus, Hypothesis 1 (see 'Introduction'), that all scours that are evident on the seafloor are incompletely colonized, cannot be accepted. For these scours, biological recolonization is a faster process than physical degradation.

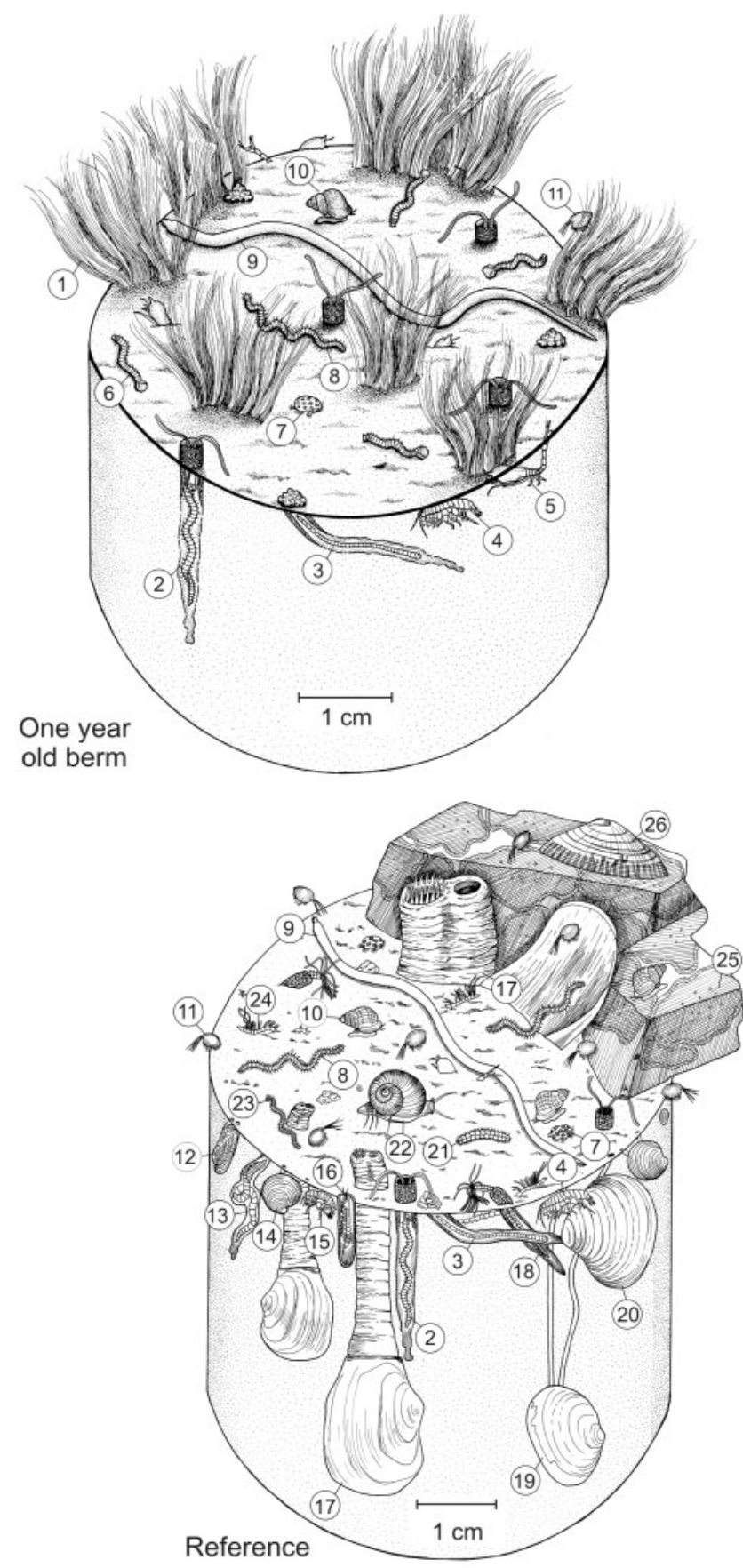

Fig. 8. Communities of core-collected fauna in a 1 yr old berm compared to reference community. 1: Parlibellus sp.; 2: spionid polychaete; 3: capitellid polychaete; 4: Monoculodes vibei Just; 5: cumacean crustacean; 6: Ophryotrocha spatula Fournier and Conlan; 7: podocopid ostracod crustacean; 8: Nereimyra punctata Müller; 9: nemertean; 10: Onoba mighelsi (Stimpson); 11: Philomedes sp.; 12: Lyonsia arenosa (Möller); 13: paraonid polychaete; 14: Astarte borealis (Schumacher); 15: Guernea nordenskioldi (Hansen); 16: tanaid

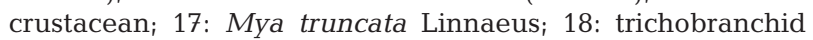
polychaete; 19: Macoma calcarea (Gmelin); 20: Serripes groenlandicus (Mohr); 21: Pholoe minuta (Fabricius); 22: Margarites sp.; 23: syllid polychaete; 24: cirratulid polychaete; 25: Lithothamnion sp.; 26: Tectura testudinalis (Müller) 
ANOSIM 1-R values significantly correlated with physical estimates of the scour ages. Thus Hypothesis 2 can be accepted that community composition of the scours reflects their physical state of degradation. Correlation was lower when full community composition was used for comparison (Table 3). However, other physical criteria, such as sediment grain size and scour size and angle of incision, gave lower correlations still. Snelgrove \& Butman (1994) and Dernie et al. (2003) question the use of gross sediment characteristics for benthic studies. Relevant changes may be too subtle for granulometric detection methods and may only occur at the sediment-water interface. In the Barrow Strait ice scours, a more obvious measure of physical ageing was a change in sediment texturing from flattened clay with embedded cobble in new scours to an increasingly cobble-armor covering the underlying clay. This change in surface texturing of the seabed may have influenced colonization by altering the hydrodynamics of the benthic boundary layer. Reduced topographic relief due to erosion of the berms would also change the strength and direction of bottom currents as the scours aged, thereby influencing recruitment and community living conditions (Snelgrove \& Butman 1994). The significant correlation of faunal patterns with age of disturbance supports the intermediate disturbance hypothesis (Connell 1978, Huston 1979, Paine \& Levin 1981), whereby succession occurs as the disturbance ages, creating a high diversity over all scour ages combined.

None of the known-age scours (those $\leq 9 \mathrm{yr}$ ) had completed recolonization at the last time of sampling (Fig. 3: $1-\mathrm{R}<0.8)$. Recolonization in these scours fitted a positive linear model (with the exception of the 'Lower Molar' berm where community resemblance to reference was more variable over time). Insufficient time series collections were taken of older scours to know whether the rate of recolonization slowed to a plateau. Assuming linearity for the full recovery sequence, the scours were 5 to $7 \mathrm{yr}$ old when recolonization was halfway complete $(1-\mathrm{R}=0.4)$ (Fig. 3$)$. The small setbacks in recolonization seen for both 'Incisor' and 'Lower Molar' (Fig. 3) were not likely to have been due to sampling year, as the years in which 'Incisor' was aged 3 to 5 (1993 to 1995) did not correspond with the years in which 'Lower Molar' was at this age (1992 to 1994).

Soft-bottom plowing disturbances may be generated by ice, anchors, dredging and trawling and seabed mining, or by feeding activities of such large predators as gray whales (Oliver \& Slattery 1985) and rays (vanBlaricom 1982). Commercial trawling can reach depths of down to $1200 \mathrm{~m}$ (Cryer et al. 2002). Besides impacting the resident benthos, these disturbances alter the physical habitat, sedimentation and nutrient cycling
(Hotzel \& Miller 1983, Churchill 1989, Lewis \& Blasco 1990, Mayer et al. 1991). There is some comparative information on rates of recolonization of benthic macrofauna. At least 7 yr was needed for abyssal benthos in the Peru Basin to recover following seabed ploughing to simulate deep-sea mining (Bluhm 2001). Newell et al. (1998), Collie et al. (2000) and Jennings et al. (2001) cite papers indicating recovery rates from dredging of $<1$ to $>15 \mathrm{yr}$, depending on latitude, sediment type and source-community characteristics. Gutt et al. (1996) estimate a recolonization time of $>230 \mathrm{yr}$ for Antarctic benthos at 100 to $500 \mathrm{~m}$ depth and $53 \mathrm{yr}$ for Arctic benthos at 0 to $70 \mathrm{~m}$ depth after ice scour. However, they based their estimates on estimated rescour rate, not empirical data on benthic recolonization rate. Factors affecting recolonization of such disturbances are the timing, size, type, location and frequency of disturbance, physico-chemical characteristics and natural stability of the system, supply of colonizers, characteristics of the colonizers, and biological interactions among the colonists (Sousa 1985, McCook 1994, Newell et al. 1998, Collie et al. 2000, Jennings et al. 2001). Disturbed habitats that are permanently altered, as may occur with dredging, may be populated by a different suite of organisms (Desprez 2000, Frid et al. 2000). The way the disturbances erode and infill will also affect colonization (Dernie et al. 2003). For example, gray whale and ray feeding depressions infill with wood debris and detritus (vanBlaricom 1982, Oliver \& Slattery 1985). Ice scours near macroalgae similarly infill with algal detritus (Richardson \& Hedgpeth 1977). These depressions are catchments for settling larvae and provide food and shelter for colonizing fauna (Aller \& Aller 1986, Snelgrove 1994). In Barrow Strait, strong currents prevent infilling of the scour depressions and so the scours modify by erosion and tumble-down (Blasco et al. 2000). They are slow to degrade physically because they become armored with age. Dernie et al.'s (2003) recommendation of using infill rate as a predictor of biological recovery would not be desirable for Barrow Strait, however, as the latter is completed well before the former. Ice scours in the coastal Beaufort Sea, which are under the influence of the sediment-laden Mackenzie River, may be aged by infilling (Lewis \& Blasco 1990). Colonization of ice scours in Resolute Bay (adjacent to Barrow Strait) is affected by winter infill of brine, which causes the scour depressions to turn hypoxic and kill residents or immigrants (Kvitek et al. 1998). Recolonization of ice scours in the Antarctic may be slower than in the Arctic because the former occur in a greater range of water depths (Barnes \& Lien 1988) and the source community in deep water is dominated by large, slow-growing sponges (Gutt \& Starmans 2001, Gerdes et al. 2003, Gutt \& Piepenburg 2003). 
Thus, the strength of the link of biological recovery to physical degradation (Dernie et al. 2003) is probably variable and site-specific.

If one were to consider that recolonization is not complete until all organisms reach full size, as was done by Arntz et al. (1994) and Peck et al. (1999) for benthic recolonization of Antarctic ice scours, it would be necessary to base recolonization rate on the slowest-growing organism. Welch et al. (1992) estimated that it would take 55 yr for the largest clam in Barrow Strait, Mya truncata, to reach maximal size. Dernie et al. (2003) used abundance as a proxy for the recovery of a temperate intertidal soft-sediment community, as this measure showed the clearest response to disturbance. These simple measures may over- or underestimate community change, however, depending on the characteristics of the source community. In the Barrow Strait core-collected communities, abundance, diversity and biomass were restored to reference levels within $4 \mathrm{yr}$, which was at least twice the rate of community recovery as measured by the ANOSIM R statistic. Newell et al. (1998) suggest that a practical definition of 'recovery' is the establishment of a community that is capable of maintaining itself and in which at least $80 \%$ of the species diversity and biomass has been restored. However, high diversity can be achieved in communities that are not fully recolonized, owing to lesser competition for resources (Connell 1978). As demonstrated by Warwick \& Clarke (1991), community composition is a more sensitive measure of change than any univariate measure. Thus, the ANOSIM R statistic should be considered a valuable measure of community recovery.

We hypothesized (Hypothesis 3) that scour berms would differ in community makeup from the centrally incised trough. Berms on new scours were soft and blocky and there was some evidence that currents were higher (authors' unpubl. data). Troughs were compressed and received tumble-down of cobble as the berms eroded. Troughs became physically indistinguishable from reference areas sooner than berms. Thus, newly protruded berms might enable colonizers to reach them sooner and burrow into the sediment than hard packed troughs with a lower current. Longer-term colonization might speed up in the troughs, however, as they returned to reference conditions sooner than the berms. It was found, however, that abundance, biomass and diversity in the trough communities correlated significantly with the berms as recolonization progressed (Spearman rank correlation, Fig. 5). The progress of recolonization (ANOSIM 1-R values) for troughs and berms was also significantly correlated (Pearson correlation $=0.757, \mathrm{p}=0$ ). Thus, the pattern and rate of species composition of the colonizing communities was similar in the 2 contours, at least within our sampling time frame.
We also hypothesized that ice scours, because of their different physical distinctiveness and the wall effect of the berms, could become refugia for disturbance-associated fauna (Hypothesis 4). This was true for the dorvilleid polychaete Ophryotrocha spatula (see Fournier \& Conlan 1994) on this coast. It was abundant in young scours and nearly absent in older scours or in undisturbed sediment (Fig. 5). Ophryotrocha spp. are also favored by ice scour in McMurdo Sound and Arthur Harbor, Antarctica (Richardson \& Hedgpeth 1977, Lenihan \& Oliver 1995, Bromberg et al. 2000) and by organic enrichment (Grassle \& MorsePorteous 1987, Lenihan et al. 1990, Hall et al. 1997, Conlan et al. 2004) and other sources of sulfidic sediments (Levin et al. 2003). Their absence later suggests that they are intolerant to the physico-chemical conditions and/or the 'climax' community present outside the scours. In the deep sea, their abundance is maintained by patchy supplies of organic enrichments (Grassle \& Morse-Porteous 1987).

Other taxa that were early colonists of scours but persisted as the scours aged were cumaceans, ophiuroids, juvenile bivalves (Serripes groenlandicus and other unidentifiable species), the oedicerotid amphipod Monoculodes spp., the hesionid polychaete Nereimyra punctata, and various species of capitellid, phyllodocid and spionid polychaetes (Fig. 5). The spionid polychaete Spiophanes tcherniae dominates both young and old ice scour disturbances in the Weddell Sea, Antarctica (Gerdes et al. 2003). Some of these ice scour pioneers (e.g. species of Nereimyra, Capitella and Monoculodes, and spionid polychaetes) are also associated with other kinds of disturbance (Grassle \& Grassle 1974, McCauley et al. 1976, Pearson \& Rosenberg 1978, Mirza \& Gray 1981, Thistle 1981, Schram \& Haaland 1984, Grassle \& Morse-Porteous 1987, Tsutsumi 1990, Bridges et al. 1994, Snelgrove et al. 1994, 1999, Hall \& Frid 1998, Nilsson \& Rosenberg 2000). As the scours age, other species colonize, particularly a diversity of bivalves, gastropods, ostracods, tanaids, and ampharetid and paranoid polychaetes (Fig. 6). Most early colonizers persist despite increasing numbers of later colonists. This does not follow the trend in recolonization portrayed by Petraitis et al. (1989), with the young scours dominated by immigration and the older by extinction. Different colonists in the ice scour depressions may also make them attractive for large surface-foragers, which in turn influence recolonization (Antarctic nototheniid fishes: Brenner et al. 2001; snow geese in the Gulf of St. Lawrence: Bélanger \& Bédard 1994, 1995; sea urchins in Barrow Strait: authors' unpubl. data).

Species richness increased rapidly after scouring, achieving that found in some reference sites within 1 to 3 yr (Fig. 3). Even when the scour community was sig- 
nificantly different from the reference community (1-R $<0.8$ ), it was taxonomically diverse and not overly dominated. Species richness and taxonomic diversity of the scour community rarely exceeded the range found in the reference community at any stage of recolonization, however. The early dominants were similar in taxonomic composition but differed from the later dominants in having a greater proportion of predators, and more species that lived just below the sediment surface. Later dominants were more variable in burrowing strategy (surface, subsurface or deeper burrower) and comprised more suspension-feeding bivalves. The differences may relate to supply of recruits, predation and competitive interactions, and differences in the physico-chemical conditions of the sediment. New scours are mixed cobble and clay which has not been previously exposed to overlying water and therefore is probably nutrient-rich, as suggested by the abundant diatom growth that occurs soon after scouring. The berms are also uncompacted. In older scours, the clay is eroded and coated by cobble, providing cover for surface-living species. The decline of diatom growth in older scours suggests that sediment nutrient levels may also decline. Sea urchins immigrated into older scours, and they feed widely on macroalgae, diatoms and invertebrates (Lawrence 1975, unpubl. data). These trends in recolonization were similar to those implied for community changes in Antarctic ice scours (Gutt \& Starmans 2001, Gerdes et al. 2003, Gutt \& Piepenburg 2003). Thus, the scours selected for different components of the reference community as they aged. The co-existence of early and late colonists may be aided by the higher recruitment rate of opportunists offsetting the superior competitive powers of the later colonists (Reice 1994). Continuous production of nearby new scours would maintain source supplies of pioneering species for older scours.

We hypothesized that reference areas vulnerable to scouring would support different communities than reference areas protected from disturbance (Hypothesis 5). Most early-colonizing species declined in abundance as the scours aged, but did not disappear (Fig. 5). The persistence of these early colonizers in sediment that has no physical evidence of scouring may be enabled by even infrequent scouring, although the re-scour interval may be greater than an individual life span. Based on age estimates by Welch et al. (1992) that the clam Mya truncata reaches $55 \mathrm{yr}$ in Barrow Strait, it can be hypothesized that the reference community outside the scours is undisturbed for at least this time because it harbors large specimens of this species. This is a long cycle-time to harbor residual scour-related species, yet the finding that faunal diversity, abundance and biomass were significantly lower in a nearby area that was protected from ice impact by an offshore rise (Fig. 7) suggests that even such long intervals as $\geq 55$ yr may provide sufficiently frequent disturbance to influence community structure. No unique species group appeared to typify this protected area, however. There was no suite of climax species that dominated the undisturbed area but was held in abeyance by disturbance. Both the chronic and protected areas supported a similar mix of species, comprising both the ubiquitous, early-colonizing species and those that appear later. However, where disturbance was a chronic, although infrequent, occurrence, a greater diversity, biomass and abundance of fauna was also present. Indeed, abundance in the chronically disturbed area was 1.3 times greater than in the area protected from ice disturbance. It is largely the bivalve component that accounted for the greater biomass in the chronically scoured area, suggesting that ice scour disturbance may enhance recruitment and/or growth. Thus, these differences in community structure support the intermediate disturbance hypothesis (Connell 1978, Huston 1979) whereby moderate amounts of ice scour promote the coexistence of a diversity of organisms and living strategies. 'Moderate' for the Barrow Strait study area is a scour rate of 1 to 7 scours $\mathrm{yr}^{-1}$ at water depths of 10 to $30 \mathrm{~m}$ (Blasco et al. 2000). This amounts to a maximum of 1.1 events $\mathrm{km}^{-1} \mathrm{yr}^{-1}$ compared to up to 8.2 events $\mathrm{km}^{-1} \mathrm{yr}^{-1}$ in 22 to $25 \mathrm{~m}$ water depth in the Canadian Beaufort Sea (Lewis \& Blasco 1990). Where disturbance is reduced, species are eliminated by competitive exclusion and diversity is therefore reduced (Connell 1978). At Signy Island, Antarctica, nearshore diversity is greatest where scour frequency is about once every $10 \mathrm{yr}$ (Barnes 1999).

The slower initial colonization of the scours 'Flat-top' and 'Groovy' may be related to their greater distance from the unscoured reference community than was the case for the other scours studied, which were single incisions. 'Flat-top' was an elevated scour, occurring on the terminal berm of Incisor when it was 4 yr old. This berm was about $4 \mathrm{~m}$ above the reference seabed. 'Groovy' was a multi-keeled scour, with the sampled berm and trough being separated from the outside reference community by a shallower trough and berm. Alternatively, the scours may have been produced closer to the time of collection than for other scours. This may have been the case for 'Flat-top', where the raised, soft 'Incisor' berm could have yielded to drifting ice keels soon before summer sampling began. It was not the case for Groovy, which was formed over the fall-winter of 1994 to 1995 . The presence of early colonists $\geq 0.25 \mathrm{~mm}$ on 'Flat-top' suggests that colonization on this raised scour was mainly by larval supply rather than by immigration of adults.

Large, multi-keeled scours such as 'Groovy' offer an opportunity for replicating samples from troughs and 
berms of identical age and also for studying variation of recolonization in a gradient of distance from the undisturbed community outside. Unfortunately, inclement diving conditions caused by frequent accumulations of large patches of drift ice limited scour access to $30-50 \%$ of the field season each year, thus preventing more extensive study. The fractures inside the trough of 'Groovy' were attractive habitats for colonization. The abundant diatoms and deposit-feeding pioneers within the fractures suggest that these scour depressions are protected from the strong tidal currents in Barrow Strait and are depositional and nutrient-rich.

In a warmer atmosphere, increased calving of icebergs and other deep-keel structures such as ice shelves may increase the frequency of seabed disturbance by ice. The zone of disturbance would also expand as deep-draft ice keels become more frequent. Alternatively, sea-ice shrinking may increase the amount of open water, providing greater room for increased ice dynamics and ice-ridging. However, seaice thinning may result in decreased draft of sea-ice keels (Wadhams 2000). During 1990 to 2003, Blasco et al. (2004) found a $40 \%$ reduction in the number of ice scours incising $>0.5 \mathrm{~m}$ seabed in 6 to $60 \mathrm{~m}$ water depth in the Canadian Beaufort Sea compared to 1979 to 1990. During 1987 to 1994, Johannessen et al. (1995) found a $54000 \pm 0.017 \mathrm{~km}^{2} \mathrm{yr}^{-1}$ decrease in Arctic sea-ice extent and a $32000 \pm 0.008 \mathrm{~km}^{2} \mathrm{yr}^{-1}$ decrease during 1978 to 1987 . Both decreases were significant ( $p<0.05$ ). A $3 \%$ per decade loss of sea ice area calculated from 3 decades of satellite observations is a modest rate, however, and is within the range of natural variability (Holloway \& Sou 2001). A robust characterization of Arctic sea-ice volume from $50 \mathrm{yr}$ models consists of increasing volume to the mid-1960s, no significant trend to the mid-1980s, and a loss of volume to the mid-1990s (Holloway \& Sou 2002). The lower volume in the $1990 \mathrm{~s}$ is attributed to belowaverage thermodynamic growth, moderated by belowaverage exports (mostly via Fram Strait). The decreased amount of ice scour in the Beaufort during the 1990s may relate to this lower thermodynamic growth or to a regional shift in moving ice.

In summary, (1) ice-scouring of the high current, glacial till seabed of Barrow Strait produced seabed incisions that lasted longer than the community impact. Over the $9 \mathrm{yr}$ of this study, none of the knownage scours had yet completed recolonization but the 2 with the longest time series of sampling were 65 to $84 \%$ complete (assuming a linear model for recolonization). By physical criteria they still had an estimated $\geq 40$ yr before the scours would no longer be visible. (2) Despite differences in contour, trough and berm communities recolonized in a similar pattern and rate. (3) The pioneering polychaete Ophyrotrocha spatula was limited to young scour communities but other pioneers persisted as later colonists recruited. (4) Benthos protected from even infrequent disturbance differed in composition and was less abundant, massive and speciose than benthos prone to occasional disturbance. Thus, ice scour appears to have a positive effect on coastal benthic diversity on this coast provided that high scour-frequency or brine infill (Kvitek et al. 1998) does not prevent recolonization.

Acknowledgements. We would like to thank the following for their long hours of assistance in often difficult working conditions in the Arctic. S. Blasco and B. Harmes of the Geological Survey of Canada and their co-workers collected the sidescan images and analyzed sediment grain size. R. Myers, Canadian Seabed Research Ltd, produced the sidescan mosaics. SCUBA diving, boat operations, and biological analyses were conducted by D. Bockus, K. Carlson, J. \& K. Conlan, J. Engel, G. Gilbert, E. Hendrycks, P. Iampietro, K. Israel, S. Kim, B. Konar, R. Kvitek, S. Lamerdin, H. Lenihan, C. Malzone, J. Oliver, R. Smith and R. Walder. K. Rodriguez, N. Goldberg and R. Rooney sorted and curated specimens, and C. Biermann, J. Fournier, J.-M. Gagnon, E. Hendrycks and A. Martel assisted with identifications. J. Whall assisted with data verification, D. Naughton and C. McClelland assisted with Fig. 1, and J. Grice gave statistical advice. We are especially grateful to members of the hamlet of Resolute Bay (H. Kalluk, N. Kalluk, I. Kalluk, and P. Amarualik), staff of the Polar Continental Shelf Project, Natural Resources Canada, and Fisheries and Oceans Canada (H. Welch) for logistic support. This work was licensed by the Nunavut Research Institute and the Baffin Region Inuit Association. We thank the Canadian Museum of Nature, the National Geographic Society, the National Science Foundation (OPP-9321504), and the Royal Canadian Geographic Society for financial support. Finally, we thank 3 anonymous reviewers for their constructive critiques.

\section{LITERATURE CITED}

Aller JY, Aller RC (1986) Evidence for localized enhancement of biological activity associated with tube and burrow structures in deep-sea sediments at the HEBBLE site, western North Atlantic. Deep-Sea Res 33:755-790

Arntz WE, Brey T, Gallardo VA (1994) Antarctic zoobenthos. Oceanogr Mar Biol Annu Rev 32:241-304

Barnes DKA (1999) The influence of ice on polar nearshore benthos. J Mar Biol Assoc UK 79:401-407

Barnes PW, Lien R (1988) Icebergs rework shelf sediments to $500 \mathrm{~m}$ off Antarctica. Geology 16:1130-1133

Barnes RD (1980) Invertebrate zoology, 4th edn. Saunders College, Philadelphia, PA

Bélanger L, Bédard J (1994) Role of ice scouring and goose grubbing in marsh plant dynamics. J Ecol 82:437-445

Bélanger L, Bédard J (1995) Use of ice-scoured depressions by marsh-foraging snow geese (Chen caerulescens atlantica). Can J Zool 73:253-259

Bernard FR (1979) Bivalve mollusks of the western Beaufort Sea. Contrib Mar Sci 313:1-80

Blasco SM, Harmes RA, Myers R, Kvitek R, Conlan K (2000) Ice scour morphology, degradation processes and seabed impact rates, Resolute Bay, Cornwallis Island, Central 
Canadian Arctic. In: Phillips R (ed) International Arctic Marine Pipelines and Sea-ice Scouring Workshop, Mombetsu, Japan, February 6-10, 2000. Program with abstracts. Centre for Cold Ocean Research and Engineering, Memorial University, St. John's, NF,

Blasco SM, Shearer JM, Campbell P, Wright B, Melling H (2004) Reduction in sea ice scour impact rates on the seabed 1979 to 2003, Canadian Beaufort Sea. In: Phillips R (ed) Canada, EOF Trans Agu, 86(M). Joint Assembly Suppl Abstracts, p SUPP 1-8

Bluhm H (2001) Re-establishment of an abyssal megabenthic community after experimental physical disturbance of the seafloor. Deep-Sea Res II 48:3841-3868

Brenner M, Buck BH, Cordes S, Dietrich L and 6 others (2001) The role of iceberg scours in niche separation within the antarctic fish genus Trematomus. Polar Biol 24:502-507

Bridges TS, Levin LA, Cabrera D, Plaia G (1994) Effects of sediment amended with sewage, algae, or hydrocarbons on growth and reproduction in two opportunistic polychaetes. J Exp Mar Biol Ecol 177:99-119

Bromberg S, Ferrax Nonato E, Navajas Corbisier T, Varella Petti MA (2000) Polychaete distribution in the near-shore zone of Martel Inlet, Admiralty Bay (King George Island, Antarctica). Bull Mar Sci 67:175-188

Brusca RC, Brusca GJ (1990) Invertebrates. Sinauer Associates, Sunderland, MA

Chapman MG (1998) Relationships between spatial patterns of benthic assemblages in a mangrove forest using different levels of taxonomic resolution. Mar Ecol Prog Ser 162: $71-78$

Churchill JH (1989) The effect of commercial trawling on sediment resuspension and transport over the Middle Atlantic Bight continental shelf. Cont Shelf Res 9:841-864

Clarke KR (1993) Non-parametric multivariate analyses of changes in community structure. Aust J Ecol 18:117-143

Clarke KR, Ainsworth M (1993) A method of linking multivariate community structure to environmental variables. Mar Ecol Prog Ser 92:205-219

Clarke KR, Green RH (1988) Statistical design and analysis for a 'biological effects' study. Mar Ecol Prog Ser 46:213-226

Clarke KR, Warwick RM (2001) Change in marine communities: an approach to statistical analysis and interpretation, 2nd edn. PRIMER-E, Plymouth

Collie JS, Hall SJ, Kaiser MJ, Poiner IR (2000) A quantitative analysis of fishing impacts on shelf sea benthos. J Anim Ecol 69:785-798

Conlan KE, Lenihan HS, Kvitek RG, Oliver JS (1998) Ice scour disturbance to benthic communities in the Canadian High Arctic. Mar Ecol Prog Ser 166:1-16

Conlan KE, Kim SL, Lenihan HS, Oliver JS (2004) Benthic changes during 10 years of organic enrichment by McMurdo Station, Antarctica. Mar Pollut Bull 49:43-60

Connell JH (1978) Diversity in tropical rain forests and coral reefs. Science 199:1302-1310

Cryer M, Hartill B, O'Shea S (2002) Modification of marine benthos by trawling: toward a generalization for the deep ocean? Ecol Appl 12:1824-1839

Dauvin JC, Gomez Gesteira JL, Salvande Fraga M (2003) Taxonomic sufficiency: an overview of its use in the monitoring of sublittoral benthic communities after oil spills. Mar Pollut Bull 46:552-555

De Biasi AM, Bianchi CN, Morri C (2004) Analysis of macrobenthic communities at different taxonomic levels: an example from an estuarine environment in the Ligurian Sea (NW Mediterranean). Estuar Coast Mar Sci 58:99-106

Dernie KM, Kaiser MJ, Warwick RM (2003) Recovery rates of benthic communities following physical disturbance.
J Anim Ecol 72:1043-1056

Desprez M (2000) Physical and biological impact of marine aggregate extraction along the French coast of the Eastern English Channel: short- and long-term post-dredging restoration. ICES J Mar Sci 57:1428-1438

Dionne JC (1977) Relict iceberg furrows on the floor of glacial lake Ojibwa, Québec and Ontario. Marit Sediments 13: 79-81

Dowdeswell JA, Villinger $\mathrm{H}$, Whittington RJ, Marienfeld P (1993) Iceberg scouring in Scoresby Sund and on the East Greenland continental shelf. Mar Geol 111:37-53

Fauchald K, Jumars PA (1979) The diet of worms: a study of polychaete feeding guilds. Oceanogr Mar Biol Annu Rev 17:193-284

Fournier JA, Conlan KE (1994) A new species of Ophryotrocha (Polychaeta, Dorvilleidae) associated with ice scours in the Canadian Arctic Archipelago. In: Dauvin JC, Laubier L, Reish DJ (eds) Actes de la 4ème conférence internationale des polychètes. Mem Mus Natl Hist Nat 162:185-190

Frid CLJ, Harwood KG, Hall SJ, Hall JA (2000) Long-term changes in the benthic communities on North Sea fishing grounds. ICES J Mar Sci 57:1303-1309

Gerdes D, Hilbig B, Montiel A (2003) Impact of iceberg scouring on macrobenthic communities in the high-Antarctic Weddell Sea. Polar Biol 26:295-301

Grass J (1998) Ice scours and ice ridges of Lake Erie, Ontario, Canada. In: Phillips R (ed) Proc Ice Scour and Arctic Marine Pipelines Workshop, 13th Int Symp Okhotsk Sea and Sea Ice, Mombetsu, Hokkaido, Japan, February 1-4, 1998. Centre for Cold Ocean Research and Engineering, Memorial University, St. John's, NF

Grassle JF, Grassle JP (1974) Opportunistic life histories and genetic systems in marine benthic polychaetes. J Mar Res 32:253-284

Grassle JF, Morse-Porteous LS (1987) Macrofaunal colonization of disturbed deep-sea environments and the structure of deep-sea benthic communities. Deep-Sea Res 34: $1911-1950$

Gutt J (2001) On the direct impact of ice on marine benthic communities, a review. Polar Biol 24:553-564

Gutt J, Piepenburg D (2003) Scale-dependent impact on diversity of Antarctic benthos caused by grounding of icebergs. Mar Ecol Prog Ser 253:77-83

Gutt J, Starmans A (2001) Quantification of iceberg impact and benthic recolonisation patterns in the Weddell Sea (Antarctica). Polar Biol 24:615-619

Gutt J, Starmans A, Dieckmann G (1996) Impact of iceberg scouring on polar benthic habitats. Mar Ecol Prog Ser 137: 311-316

Hall JA, Frid CLJ (1998) Colonisation patterns of adult macrobenthos in a polluted north sea estuary. Aquat Ecol 33: $333-340$

Hall JA, Frid CLJ, Gill ME (1997) The response of estuarine fish and benthos to an increasing discharge of sewage effluent. Mar Pollut Bull 34:527-535

Holloway G, Sou T (2001) Is Arctic sea ice rapidly thinning? Meridian fall-winter 2001:8-10

Holloway G, Sou T (2002) Has Arctic sea ice rapidly thinned? J Climate 25:1691-1701

Hotzel SI, Miller JD (1983) Icebergs: their physical dimensions and the presentation and application of measured data. Annu Glaciol 4:116-123

Hurlbert SH (1984) Pseudoreplication and the design of ecological field experiments. Ecol Monogr 54:187-211

Huston M (1979) A general hypothesis of species diversity. Am Nat 113:81-101 
Jennings S, Pinnegar JK, Polunin NVC, Warr KJ (2001) Impacts of trawling disturbance on the trophic structure of benthic invertebrate communities. Mar Ecol Prog Ser 213: $127-142$

Johannessen OM, Miles M, Bjørgo E (1995) The Arctic's shrinking sea ice. Nature 376:126-127

Jones JB (1992) Environmental impact of trawling on the seabed: a review. NZ J Mar Freshw Res 26:59-67

Josenhans H, Woodworth-Lynas CMT (1988) Enigmatic linear furrows and pits on the upper continental slope, northwest Labrador Sea: are they sediment furrows or feeding traces? Marit Sediments Atl Geol 24:149-155

Knust R, Arntz WE, Boche M, Brey T and 5 others (2003) Iceberg scouring on the eastern Weddell Sea shelf (Antarctica): a benthic system shaped by physical disturbances? In: Huiskes AHL, Gieskes WWC, Rozema J, Schorno RML, van der Vies SM, Wolff WJ (eds) Antarctic biology in a global context. Backhuys Publishers, Leiden, p 96-101

Kvitek RG, Conlan KE, Iampietro PJ (1998) Black pools of death: hypoxic, brine-filled ice gouge depressions become lethal traps for benthic organisms in a shallow Arctic embayment. Mar Ecol Prog Ser 162:1-10

Lawrence JM (1975) On the relationships between marine plants and sea urchins. Oceanogr Mar Biol Annu Rev 13: 213-286

Lee HJ, Gerdes D, Vanhove S, Vincx M (2001a) Meiofauna response to iceberg disturbance on the Antarctic continental shelf at Kapp Norvegia (Weddell Sea). Polar Biol 24:926-933

Lee HJ, Vanhove S, Peck LS, Vincx M (2001b) Recolonisation of meiofauna after catastrophic iceberg scouring in shallow Antarctic sediments. Polar Biol 24:918-925

Lenihan HS, Oliver JS (1995) Anthropogenic and natural disturbances to marine benthic communities in Antarctica. Ecol Appl 5:311-326

Lenihan HS, Oliver JS, Oakden JM, Stephenson MD (1990) Intense and localized benthic marine pollution around McMurdo Station, Antarctica. Mar Pollut Bull 21:422-430

Levin LA, Ziebis W, Mendoza GF, Growney VA and 5 others (2003) Spatial heterogeneity of macrofauna at northern California methane seeps: influence of sulfide concentration and fluid flow. Mar Ecol Prog Ser 265:123-139

Lewis CFM, Blasco SM (1990) Character and distribution of sea-ice and iceberg scours. In: Clark JI (ed) Workshop on Ice Scouring and Design of Offshore Pipelines, Calgary, Alberta, April 18-19 1990. Canada Oil and Gas Lands Administration, Energy, Mines and Resources Canada and Indian and Northern Affairs Canada, Ottawa, p 57-101

Lien R, Solheim A, Elverhøi A, Rokoengen K (1989) Iceberg scouring and sea bed morphology on the eastern Weddell Sea shelf, Antarctica. Polar Res 7:43-57

MacArthur RH, Wilson EO (1967) Theory of island biogeography. Princeton University Press, Princeton, NJ

Mayer LM, Schick DF, Findlay RH, Rice DL (1991) Effects of commercial dragging on sedimentary organic matter. Mar Environ Res 31:249-261

McCauley JE, Hancock DR, Parr RA (1976) Maintenance dredging and four polychaete worms. In: Krenkel J, Harrison PA, Burdick JC III (eds) Proc Specialty Conf Dredging and Its Environmental Effects. American Society of Engeers, New York, p 673-683

McCook LJ (1994) Understanding ecological community succession: causal models and theories, a review. Vegetatio 110:115-147

McCook LJ, Chapman ARO (1993) Community succession following massive ice-scour on a rocky intertidal shore: recruitment, competition and predation during early, primary succession. Mar Biol 115:565-575

Mirza FB, Gray JS (1981) The fauna of benthic sediments from the organically enriched Oslofjord, Norway. J Exp Mar Biol Ecol 54:181-207

Newell RC, Seiderer LJ, Hitchcock DR (1998) The impact of dredging works in coastal waters: a review of the sensitivity to disturbance and subsequent recovery of biological resources on the sea bed. Oceanogr Mar Biol Annu Rev 36:127-178

Nilsson HC, Rosenberg R (2000) Succession in marine benthic habitats and fauna in response to oxygen deficiency: analyzed by sediment profile-imaging and by grab samples. Mar Ecol Prog Ser 197:139-149

Oliver JS, Slattery PN (1985) Destruction and opportunity on the sea floor: effects of gray whale feeding. Ecology 66: 1965-1975

Paine RT, Levin SA (1981) Intertidal landscapes: disturbance and the dynamics of pattern. Ecol Monogr 51:145-178

Pearson TH, Rosenberg R (1978) Macrobenthic succession in relation to organic enrichment and pollution of the marine environment. Oceanogr Mar Biol Annu Rev 16:229-311

Peck LS, Brockington S, Vanhove S, Beghyn M (1999) Community recovery following catastrophic iceberg impacts in a soft-sediment shallow-water site at Signy Island, Antarctica. Mar Ecol Prog Ser 186:1-8

Pereira CPG, Piper DJW, Shor AN (1985) SeaMARC I midrange sidescan sonar survey of Flemish Pass, east of the Grand Banks of Newfoundland. Geol Surv Can Open File Rep 1161, Natural Resources Canada, Ottawa

Petraitis PS, Latham RE, Niesenbaum RA (1989) The maintenance of species diversity by disturbance. Q Rev Biol 64: 393-418

Philippi TE, Dixon PM, Taylor BE (1998) Detecting trends in species composition. Ecol Appl 8:300-308

Rearic DM, Barnes PW, Reimnitz E (1990) Bulldozing and resuspension of shallow-shelf sediment by ice keels: implications for Arctic sediment transport trajectories. Mar Geol 91:133-147

Reice SR (1994) Nonequilibrium determinants of biological community structure. Am Sci 82:424-435

Reid RGB, Reid A (1969) Feeding processes of the genus Macoma (Mollusca: Bivalvia). Can J Zool 47:649-657

Richardson MD, Hedgpeth JW (1977) Antarctic soft-bottom, macrobenthic community adaptations to a cold, stable, highly productive, glacially affected environment. In: Llano GA (ed) Adaptations within Antarctic ecosystems. Proc Third SCAR Symposium on Antarctic Biology. Smithsonian Institution, Washington, DC, p 181-196

Rouse GW, Pleijel F (2001) Polychaetes. Oxford University Press, Oxford

Schram TA, Haaland B (1984) Larval development and metamorphosis of Nereimyra punctata (O. F. Müller) (Hesionidae, Polychaeta). Sarsia 69:169-181

Service M, Magorrian BH (1997) The extent and temporal variation of disturbance to epibenthic communities in Strangford Lough, Northern Ireland. J Mar Biol Assoc UK 77:1151-1164

Snelgrove PVR (1994) Hydrodynamic enhancement of invertebrate larval settlement in micro-depositional environments: colonization tray experiments in a muddy habitat. J Exp Mar Biol Ecol 176:149-166

Snelgrove PVR, Butman CA (1994) Animal-sediment relationships revisited: cause versus effect. Oceanogr Mar Biol Annu Rev 32:111-177

Snelgrove PVR, Grassle JF, Petrecca RF (1994) Macrofaunal response to artificial enrichments and depressions in a 
deep-sea habitat. J Mar Res 52:345-369

Snelgrove PVR, Grassle JP, Grassle JF, Petrecca RF, Ma H (1999) In situ habitat selection by settling larvae of marine soft-sediment invertebrates. Limnol Oceanogr 44: 1341-1347

Somerfield PJ, Clarke KR (1995) Taxonomic levels, in marine community studies, revisited. Mar Ecol Prog Ser 127: 113-119

Sousa WP (1985) Disturbance and patch dynamics on rocky intertidal shores. In: Pickett STA, White PS (eds) The ecology of natural disturbance and patch dynamics. Academic Press, Toronto, p 101-124

Stanley SM (1970) Relation of shell form to life habits of the Bivalvia (Mollusca). Mem Geol Soc Am 125:1-296

Thistle D (1981) Natural physical disturbances and communities of marine soft bottoms. Mar Ecol Prog Ser 6:223-228

Thompson BW, Riddle MJ, Stark JS (2003) Cost-efficient methods for marine pollution monitoring at Casey Station, East Antarctica: the choice of sieve mesh-size and taxonomic resolution. Mar Pollut Bull 46:232-243

Tsutsumi H (1990) Population persistence of Capitella sp. (Polychaeta; Capitellidae) on a mud flat subject to environmental disturbance by organic enrichment. Mar Ecol Prog Ser 63:147-156

vanBlaricom GD (1982) Experimental analysis of structural regulation in a marine sand community exposed to

Editorial responsibility: Otto Kinne (Editor-in-Chief), Oldendorf/Luhe, Germany oceanic swell. Ecol Monogr 52:283-305

Wadhams P (2000) Ice in the ocean. Gordon \& Breach Science Publishers, Amsterdam

Warwick RM (1988) The level of taxonomic discrimination required to detect pollution effects on marine benthic communities. Mar Pollut Bull 19:259-268

Warwick RM, Clarke KR (1991) A comparison of some methods for analyzing changes in benthic community structure. J Mar Biol Assoc UK 71:225-244

Welch HE, Bergmann MA, Siferd TD, Martin KA, Curtis MF, Crawford RE, Conover RJ, Hop H (1992) Energy flow through the marine ecosystem of the Lancaster Sound region, Arctic Canada. Arctic 45:343-357

Woodworth-Lynas CMT, Guigné JY (1990) Iceberg scours in the geological record: examples from glacial Lake Agassiz. In: Dowdeswell JA, Scourse JD (eds) Glacimarine environments: processes and sediments. Spec Publ Geol Soc (Lond) 53:217-223

Woodworth-Lynas CMT, Josenhans HW, Barrie JV, Lewis CFM, Parrott DR (1991) The physical processes of seabed disturbance during iceberg grounding and scouring. Cont Shelf Res 11:939-961

Young CM (ed) (2002) Atlas of marine invertebrate larvae. Academic Press, London

Submitted: November 24, 2003; Accepted: June 29, 2004 Proofs received from author(s): January 14, 2005 